[Radiocarbon, Vol. 13, No. 2, 1971, P. 213-254]

\title{
GIF NATURAL RADIOCARBON MEASUREMENTS VI
}

\author{
G. DELIBRIAS, M. T. GUILLIER, and J. LABEYRIE
}

Centre des Faibles Radioactivités, Centre National de la Recherche Scientifique, (91) Gif-sur-Yvette, France

This list consists mainly of dates obtained from analysis during 1967 and 1968 of archaeologic and geologic samples. The last section deals essentially with climatic, palynologic, and sea level variation problems. All measurements of atmospheric $\mathrm{CO}_{2}$ made periodically from 1962 until end of 1970 are also published here. In agreement with international convention, all dates have been calculated on the basis of the $\mathrm{C}^{14}$ halflife of 5568 years and $95 \%$ of NBS oxalic acid as the modern reference year.

\section{ACKNOWLEDGMENTS}

Thanks are due to Mireille Rousseau for routine sample preparation and regular atmospheric $\mathrm{CO}_{2}$ collection, and to Jean-Pierre Garnier for his valuable technical assistance.

\section{SAMPLE DESCRIPTIONS \\ I. ARCHAEOLOGIC SAMPLES \\ A. France}

\section{W. France}

$$
2120 \pm 110
$$

170 B.C.

Gif-1117. Kervéo, Plomelin, Finistère

Charcoal from Iron age souterrain, Kervéo, Plomelin $\left(47^{\circ} 55^{\prime} \mathrm{N}\right.$
$4^{\circ} 10^{\prime} \mathrm{W}$ Long), Finistère. Coll. and subm. 1967 by P. R. Giot, Fac. Lat, $4^{\circ} 10^{\prime}$ W Lom , Finistère. Coll. and subm. 1967 by P. R. Giot, Fac.
Sci., Rennes. Comment: assoc. ceramics belong to La Tène I period. Date is slightly too young (Giot, 1969; Giot and Ducouret, 1968).

Gif-812. Mesperleuch, Plouhinec, Finistère

Charcoal from salt-pan brickworks of Iron age, in a clayey block, at Mesperleuch, Plouhinec $\left(48^{\circ} 00^{\prime} \mathrm{N}\right.$ Lat, $4^{\circ} 30^{\prime} \mathrm{W}$ Long), Finistère. Coll. and subm. 1967 by P. L. Gouletquer, Fac. Sci. Rennes. Comment: in good agreement (Gouletquer, 1967, 1970; Giot, 1968).

\section{Gif-748. Le Hellen, Cleder, Finistère}

$3250 \pm 115$

1300 B.C.

Charcoal from middle Bronze age barrow at Le Hellen, Cleder $\left(48^{\circ}\right.$ $40^{\prime} \mathrm{N}$ Lat, $4^{\circ} 05^{\prime} \mathrm{W}$ Long), Finistère (Le Roux, 1966). Coll. and subm. by C. T. Roux, Fac. Sci., Rennes. Comment: agrees well with date of monument (Giot, 1968; Le Roux, 1966).

\section{Gif-749. Lescongar, Plouhinec, Finistère}

Wood from grave of Early Bronze age barrow at Lescongar, Plouhinec (48 $01^{\prime} \mathrm{N}$ Lat, $4^{\circ} 30^{\prime} \mathrm{W}$ Long), Finistère (Briard, 1968; Giot, 1968). Coll. and subm. 1966 by J. Briard, Fac. Sci., Rennes. Comment: correct age for barrow of this series. 


\section{Gif-809. Kerleven, La Forêt-Fouesnant, Finistère}

Charcoal from Chamber $\mathrm{C}$ of megalithic cairn, Kerleven, La ForêtFouesnant $\left(47^{\circ} 42^{\prime} \mathrm{N}\right.$ Lat, $3^{\circ} 48^{\prime} \mathrm{W}$ Long), Finistère. Coll. and subm. 1967 by C. T. Le Roux. Comment: this cairn, of a type especially found in S Finistère, was dated by Gsy-III: $4825 \pm 125$ (R., 1966, v. 8, p. 135). Traces Late Neolithic reutilization (Le Roux and l'Helgouach, 1967; Giot, 1968).

\section{Kernonen, Plouvorn series, Finistère}

Samples from an Early Bronze age barrow, at Kernonen, Plouvorn (48 $35^{\prime} \mathrm{N}$ Lat, $4^{\circ} 03^{\prime} \mathrm{W}$ Long), Finistère. Coll. and subm. 1967 by J. Briard.

Gif-805. Kernonen A

Wood from chest containing flat axes.

Gif-806. Kernonen B

Charcoal in clayey material of barrow.

\section{Gif-807. Kernonen C}

Charcoal in soil under barrow.

General Comment: dates for Charcoals B and C are statistically consistent but too young, for an unexplained reason; wood from chest is older than expected; possibly, this one-piece chest is from a big tree trunk (Briard, 1970; Giot, 1968, 1969).

\section{Plouzévédé series, Finistère}

Charcoal from middle Bronze age barrow of Ar Reunic $\left(48^{\circ} 35^{\prime}\right.$ $\mathrm{N}$ Lat, $4^{\circ} 15^{\prime} \mathrm{W}$ Long). Coll. and subm. 1967 by J. Briard.

\section{Gif-1113. Plouzévédé A}

$3200 \pm 120$

$1.40 \mathrm{~m}$ depth in barrow, $\mathrm{N}$ and $\mathrm{E}$ trenches.

\section{Gif-1114. Plouzévédé B}

$1.20 \mathrm{~m}$ depth in barrow $\mathrm{S}$ trench. General Comment: barrow without central tomb and without grave goods, only some potsherds of middle Bronze age. Age usually found for this type of monument (Giot, 1969).

\section{Barnenez, Plouézoch series, Finistère}

Charcoal from different passage graves of great cairn of Barnenez, Plouézoch (48 $40^{\prime} \mathrm{N}$ Lat, 3 $51^{\prime} \mathrm{W}$ Long). Coll. and subm. 1967-1969 by P. R. Giot.

Gif-1116. Barnenez, Dolmen F, passage
$5100 \pm 140$

3150 B.C. 
Gif-1309. Barnenez, Dolmen G, chamber

Gif-1310. Barnenez, Dolmen A, chamber

Gif-1311. Barnenez, Dolmen B, entrance

Gif-1556. Barnenez, Chamber F, chamber
$5750 \pm 150$ 3800 в.c.

$5450 \pm 150$ 3500 в.c.

$3200 \pm 120$ 1250 B.C.

$5550 \pm 140$ 3600 B.c.

General Comment: Gif-1311, as Gsy-30 and Gsy-147 (2200 \pm 200 and $2690 \pm 105$, R., 1966, v. 8, p. 137) indicate that Megalithic site of Barnenez was re-used during Bronze and Iron ages. Gif-1116, -1309, -1310, and -1556 date 1st occupation and agree well with established chronology for construction of the different dolmens (Giot, 1969, 1970).

\section{Gif-767. Prajou menhir, Trebeurden, Finistère}

$5330 \pm 150$

Charcoal from additional hearth in megalithic monument, Prajou menhir, Trebeurden (48 $47^{\prime} 40^{\prime \prime} \mathrm{N}$ Lat, $3^{\circ} 33^{\prime} 45^{\prime \prime} \mathrm{W}$ Long), Finistère (l'Helgouach, 1966). Coll. and subm. 1966 by J. l'Helgouach, Fac. Sci., Rennes. Comment: $2000 \mathrm{yr}$ older than expected. As suggested by P. R. Giot, should be a utilization of fossil wood from nearby peat bog (Giot, 1968; l'Helgouach, 1966).

Gif-804. Le Calais, Saint-Michel-Chef-Chef, Loire Atlantique

$800 \pm 100$

A.D. 1150

Charcoal from site with "augets", pottery salt-pan, at Le Calais, Saint-Michel-Chef-Chef $\left(47^{\circ} 10^{\prime} \mathrm{N}\right.$ Lat, $2^{\circ} 09^{\prime} \mathrm{W}$ Long), Loire Atlantique (Gouletquer et al., 1968). Coll. by M. Tessier and subm. 1967 by P. L. Gouletquer. Comment: expected date: 100 B.c. (Giot, 1968).

\section{Gif-803. Kerlavos, Trégastel, Côtes du Nord}

$1500 \pm 100$

Charcoal from Hearth 3 in remains of brickworks, from salt industry site, at Kerlavos, Trégastel (48 $48^{\prime} \mathrm{N}$ Lat, $3^{\circ} 32^{\prime} \mathrm{W}$ Long), Côtes du Nord (Giot, 1965). Coll. and subm. 1967 by P. R. Giot. Comment: much later than assoc. ceramics (Giot, 1968).

\section{Gif-747. Miniou Bonen, Côtes du Nord}

$2200 \pm 105$ 250 B.C.

Charcoal from Iron age surface site at Miniou Bonen $\left(40^{\circ} 12^{\prime} \mathrm{N}\right.$ Lat, $3^{\circ} 15^{\prime} \mathrm{W}$ Long). Coll. and subm. 1966 by P. R. Giot (Le Provost and Giot, 1966; Giot, 1968). Comment: assoc. with decorated ceramics of La Tène I type. Agrees well with expected age.

\section{Gif-808. Grohan, Quessoy, Côtes du Nord}

$$
2290 \pm 100
$$

340 B.c.

Charcoal from Iron age souterrain, Grohan, Quessoy $\left(\begin{array}{ll}48^{\circ} & 22^{\prime} \mathrm{N}\end{array}\right.$ Lat, $2^{\circ} 4 \mathrm{I}^{\prime} \mathrm{W}$ Long), Côtes du Nord (Guyader, 1969). Coll. by Y. 
Guyader and subm. 1967 by P. R. Giot. Comment: correct for age of La Tène I (Giot, 1968).

\section{Gif-814. Cre'h-Quillé, Saint-Quay-Perros, $\quad 3760 \pm 120$ Côtes du Nord, $E$ entrance 1810 B.c.}

Charcoal from blocking of $\mathbf{E}$ entrance Crec'h-Quillé grave, SaintQuay-Perros (48 $47^{\prime} \mathrm{N}$ Lat, 3 23' W Long), Côtes du Nord (l'Helgouach, 1967). Coll. and subm. 1967 by J. l'Helgouach. Comment: to confirm date of Gif-344: $3740 \pm 200$ (R., 1970, v. 12, p. 430; Giot, 1968).

\section{Gif-813. Ile Geignog, Landela, Finistère 2550 B.c.}

Charcoal from Dolmen III-E, Ile Geignog, Landela $\left(48^{\circ} 35^{\prime} \mathrm{N}\right.$ Lat, $4^{\circ} 35^{\prime} \mathrm{W}$ Long). Coll. and subm. 1967 by J. l'Helgouach. Comment: this passage grave is later addition to Cairn III; date would indicate utilization during Late Neolithic. Cf. Gsy-164 B (Giot, 1968).

\section{Cap d'Erquy series, Côtes du Nord}

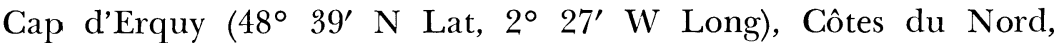
covered by remains of double entrenched camp of Protohistoric age. Under Fossé Catuélan which blocks way to extreme part of Cap, Neolithic industry was found. Fossé de Plaine-Garenne is $450 \mathrm{~m} \mathrm{E}$ of this 1st entrenchment (Giot and Briard, 1969). Charcoal coll. and subm. 1967, 1968 by P. R. Giot and J. Briard.

\section{Gif-1118. Fossé Catuélan, Erquy}

$4560 \pm 140$

Comment: dates Neolithic forest clearance.

\section{Gif-1302. Fossé de Plaine-Garenne, Erquy}

Comment: Gif-715 (R., 1970, v. 12, p. 432) dates Fossé Catuélan to late Hallstatt age; Fossé de Plaine Garenne has La Tène fortification, with interlaced timber-work.

\section{Gif-1115. Moustérian, Séné, Morbihan}

$$
\begin{array}{r}
1620 \pm 110 \\
\text { A.D. } 330
\end{array}
$$

Charcoal from Kiln c of salt-pan of sta. of Moustérian, Séné $\left(47^{\circ}\right.$ $36^{\prime} \mathrm{N}$ Lat, $2^{\circ} 44^{\prime} \mathrm{W}$ Long), Morbihan. Coll. and subm. 1967 by P. L. Gouletquer. Comment: confirms too early age: $1495 \pm 150$ B.P. for charcoal coll. in another kiln of same sta. (Gif-229, R., 1966, v. 8, p. 79). Presence of fragments of vases of "La Tène" period makes these dates inexplicable (Gouletquer et al., 1968; Giot, 1969; Gouletquer, 1970).

\section{Gif-863. Saint-Fiacre, Melrand, Morbihan}

$3900 \pm 135$

Wood from box of Early Bronze age barrow, Saint-Fiacre, Melrand (47 $58^{\prime} \mathrm{N}$ Lat, $3^{\circ} 07^{\prime} \mathrm{W}$ Long), Morbihan. Coll. 1897 by Aveneau de la Grancière and subm. 1967 by H. J. Case, Dept. of Antiquities, Ashmolean Mus., Oxford. Comment: in Ashmolean Mus. Colln. since 1925. Compares well with Gif-805 (Giot, 1969). 
Gif-458. Le Breuil-sous-Argenton, Deux-Sèvres

$1260 \pm 100$

Charcoal from moat at Le Breuil-sous-Argenton, Deux-Sèvres $\left(46^{\circ}\right.$ $59^{\prime} \mathrm{N}$ Lat, $0^{\circ} 27^{\prime} \mathrm{W}$ Long). Coll. and subm. 1965 by M. Berthod, Paris. Comment: too old for feudal moat; charcoal probably dates earlier construction, on same site.

Gif-1119. Jard-sur-Mer, Vendée

$3300 \pm 120$

(4harcolic barrow of Plage de Légère, Jard-surMer ( $46^{\circ} 25^{\prime} \mathrm{N}$ Lat, $1^{\circ} 35^{\prime} \mathrm{W}$ Long). Coll. and subm. 1967 by J. Joussaume, Inst. Paleontol. Humaine, Paris. Comment: because of assoc. Beaker pottery, somewhat earlier date was expected (Joussaume, 1968; Giot, 1969).

$\begin{array}{ll}\text { Gif-802 } & 2670 \pm 110\end{array}$

"Moulin du Fâ", Barzan, Charente Maritime 720 B.c.

Charcoal from Layer 0 under Gallo-Roman sta. of "Moulin du Fâ", Barzan (45 32' N Lat, $0^{\circ} 53^{\prime}$ W Long). Coll. and subm. 1967 by J. P. Mohen, Merignac, Dordogne. Comment: important ceramics from La Tène I and Hallstatt epochs assoc. Date corresponds with Hallstatt occupation.

\section{Gif-724. Cave of Rancogne, Charente}

$3150 \pm 110$

Charcoal $A$ found in clay deposit on 1200 B.C. Rancogne $\left(45^{\circ} 41^{\prime} \mathrm{N}\right.$ Lat, $0^{\circ} 24^{\prime} \mathrm{E}$ Long), Chell in cave of subm. 1966 by C. Burnez, Gensac-La-Pallue, Charente. Comment: dates important Urnfield site, Stage II-III.

\section{Gif-725. La Croix des Sables, Mainxe, Charente}

Charcoal in ditch around settlement site, $1.50 \mathrm{~m}$ depth, under refuse deposit with bones, ceramics, and abundant charcoal at La Croix des Sables ( $45^{\circ} 38^{\prime} \mathrm{N}$ Lat, $0^{\circ} 11^{\prime} \mathrm{W}$ Long), Charente. Coll. 1963 and subm. 1966 by C. Burnez. Comment: dates a La Tène site.

\section{S. W. France}

\section{Roanne series, Villegouge, Gironde}

Charcoal from Neolithic sta. of Roanne, Villegouge (44 $57^{\prime} \mathrm{N}$ Lat, $0^{\circ} 22^{\prime}$ W Long), Gironde. Coll. and subm. 1967 by A. Coffyn, Bordeaux.

Gif-782. Roanne F 3, 1961

From hearth found in a pit.

Gif-783. Roanne 1963

In $5 \mathrm{~cm}$ charcoal layer, under $1.70 \mathrm{~m}$ stratified levels. $\mathbf{3 8 5 0} \pm 135$

1900 B.c.

$3700 \pm 135$ 1750 B.C. 
Gif-784. Roanne 1966

From same level.

General Comment: according to assoc. ceramics, belongs to Peu-Richard culture defined in Charente, but lithic industry is slightly different. Some hundred yr younger than other dates from Charente (Gsy-32, -71: R., 1966, v. 8, p. 131-132; Gif-474, -475, -313, and -417: R., 1970, v. 12, p. 435).

\section{Auterive series, Haute Garonne}

Carbonized wood from Roman site, at Auterive $\left(43^{\circ} 20^{\prime} \mathrm{N}\right.$ Lat, $1^{\circ} 28^{\prime}$ E Long) Haute Garonne. Coll. and subm. 1966 by L. Latour, Auterive.

Gif-757. Auterive II

Upper level.

\section{Gif-756. Auterive I}

Deepest level.

General Comment: agrees well with Gif-757; but Gif-756 is several hundred yr older than expected.

\section{Gif-826. Grotte de Puech Ricard, Aveyron}

$4970 \pm 140$ 3020 B.c.

Carbonized grains in Late Neolithic grave from grotte de Puech Ricard, la Bastide-Pradines (44 $01^{\prime} \mathrm{N}$ Lat, $3^{\circ} 04^{\prime} \mathrm{E}$ Long), Aveyron. Coll. and subm. 1967 by A. Soutou, Toulouse. Comment: cf. results obtained for grotte of Sargel, near Puech-Ricard (Gif-444, -445: 4500 and 4570 в.P., R., 1970 , v. 12, p. 423$)$.

\section{Gif-827. Puech de Mus, Aveyron}

$2375 \pm 110$

425 в.C.

Charcoal from carbonized cinders from Iron age rampart of wall of Puech de Mus, Sainte-Eulalie de Cernon $\left(43^{\circ} 59^{\prime}\right.$ N Lat, $3^{\circ} 08^{\prime} \mathrm{E}$ Long), Aveyron. Coll. and subm. by A. Soutou, Toulouse. Comment: in good agreement with expected age.

\section{Gif-773. Saint-Pardoux-Le-Neuf, Haute Corrèze}

$780 \pm 90$

Charcoal from medieval hypogeum, Saint-Pardoux-Le-Neuf $\left(45^{\circ} 37^{\prime}\right.$ $\mathrm{N}$ Lat, $2^{\circ} 20^{\prime} \mathrm{E}$ Long), Corrèze. Coll. and subm. 1966 by R. Joudoux, Tulle. Comment: in expected date range.

\section{S. E., S., and Central France}

\section{Gif-759. Roc de Las Caichos, Roquefère, Aude}

$1720 \pm 110$

Charcoal from filling of cist in a dolmen, Sepulcher III, Roc de Las Caichos, Roquefère, Aude (43 $22^{\prime} \mathrm{N}$ Lat, $2^{\circ} 21^{\prime} \mathrm{E}$ Long). Coll. and subm. 1966 by J. Guilaine, Carcassonne, Aude. Comment: dates reutilization of this Megalithic monument. 
Gif-760. Cave of Chataigniers, Casenove, Vingrau, Mediterranean Pyrénées

Charcoal from sepulchral cave of Chataigniers, Casenove, Vingrau (42 $51^{\prime} \mathrm{N}$ Lat, $2^{\circ} 47^{\prime} \mathrm{E}$ Long). Coll. by Abbé Abelanet and subm. 1966 by J. Guilaine. Comment: assoc. with Early Bronze age industry of $\mathrm{W}$ Mediterranean (Guilaine and Abelanet, 1965). Somewhat younger than expected.

\section{Hypogeum of Roaix series, Vaucluse}

Charcoal from collective tomb in hypogeum of Roaix $\left(44^{\circ} 14^{\prime} \mathrm{N}\right.$ Lat, $5^{\circ} 01^{\prime}$ E Long), Vaucluse. Coll. and subm. 1967, 1970 by J. Courtin, C.N.R.S., Marseille.

\section{Gif-857. Roaix, Level 2}

Typical Chalcolithic furniture.

\section{Gif-1620. Roaix, Level 5}

Basal level.

General Comment: same age for these 2 samples is confirmed by presence of copper pearls in both levels.

\section{Gramari series, Methamis, Vaucluse}

Charcoal from Sauveterrian site of Gramari $\left(44^{\circ} 01^{\prime} \mathrm{N}\right.$ Lat, $5^{\circ} 14^{\prime}$ W Long), Methamis, Vaucluse. Coll. and subm. 1966 by M. Paccard, Velleron, Vaucluse (Paccard, 1966).

\section{Gif-752. Gramari, Level 3 A}

Industry assoc. with remains of wild horse.

Gif-753. Gramari, Levels 3 B I and 3 B 2

Underlying level $3 \mathrm{~A}$.

\section{Gif-754. Gramari, Level C 4}

Upper level of Layer C.

\section{Gif-755. Gramari, Level C 5}

The deepest level, the last one with charcoal.

General Comment (M.C.): do not agree with archaeology: Levels 3 A and $3 \mathrm{~B}$ are not within conventional limits of classical Sauveterrian, and Level C 4, which comes from a level above the others, is older. Many questions seem to remain about this site.

\section{Gif-867. Grotte Murée, Gorges du Verdon, $\quad 4740 \pm 140$ Basses Alpes 2790 B.c.}

Charcoal from Layer 10, Grotte Murée, Gorges du Verdon, Montpezat $\left(43^{\circ} 45^{\prime} \mathrm{N}\right.$ Lat, $6^{\circ} 15^{\prime} \mathrm{E}$ Long) (Courtin, 1963). Coll. and subm. 
1967 by J. Courtin. Comment: dates this layer to Middle Neolithic, as expected from archaeology.

\section{Stantare series, Sartène, Corsica}

Charcoal from bottom of 5th monolith of Alignment I of Stantare $\left(41^{\circ} 31^{\prime} \mathrm{N}\right.$ Lat, $8^{\circ} 53^{\prime} \mathrm{E}$ Long), Plateau of Cauria, Sartène, Corsica. Coll. and subm. 1968 by R. Grosjean, C.N.R.S., Paris.

Gif-1397. Stantare, Corsica 5-1968 $2120 \pm 110$ $30 \mathrm{~cm}$ depth.

\section{Gif-1396. Stantare, Corsica 4-1968}

General Comment: Gif-1396 agrees very well with archaeologic expectation, but Gif-1397 is too young.

\section{Bonifacio series, Corsica}

Charcoal from hearths in well-defined levels, from surface to 1.30 $m$ depth, in upper part of filling of Araguina rock shelter, at Bonifacio ( $41^{\circ} 22^{\prime} \mathrm{N}$ Lat, $9^{\circ} 10^{\prime}$ E Long). Coll. and subm. by R. Grosjean.

\section{Gif-776. Bonifacio, Corsica 1, 1966}

$\mathbf{3 0 4 0} \pm 110$

Level VI a, Area A 6, A 7, B 7.

Gif-777. Bonifacio, Corsica 2, 1966

1090 B.c.

Level VI d, Area A 6.

Gif-778. Bonifacio, Corsica 3, 1966

$3300 \pm 120$

1350 B.c.

Level VI f, Area A 7, B 7, B 8.

Gif-779. Bonifacio, Corsica 4, 1966

$3980 \pm 140$

Level VI, Hearth F 3.

General Comment: dates last occupation of site and end of importation of obsidian from Sardinia (Gif-778).

\section{Castello d'Araggio series, Lévie, Sartène, Corsica}

Charcoal from a Torre monument, Castello d'Araggio $\left(41^{\circ} 38^{\prime}\right.$ N Lat, $9^{\circ} 15^{\prime}$ E Long), San-Gavino di Carbini, Lévie, Sartène, Corsica. Coll. and subm. 1967 by R. Grosjean.

\section{Gif-898. Castello d'Araggio, C-Ar-2}

On Hearth A, N room. 
Gif-1000. Castello d'Araggio, C-Ar-4

$5130 \pm 130$

3180 B.c.

Central Hearth, S guard room. Comment: was supposed to be similar either to Gif-898 or -899 .

Gif-1001. Castello d'Araggio, C-Ar-1

$2930 \pm 120$

Under Hearth $\mathrm{A}, \mathrm{N}$ room.

General Comment: except for Gif-1000, results agree well with ages already obtained for Torre cult monuments in Corsica.

Curacchiaghiu series, Lévie, Corsica

Charcoal from sepulchral cave, Curacchiaghiu $\left(41^{\circ} 42^{\prime} \mathrm{N}\right.$ Lat, $9^{\circ} 8^{\prime}$

E Long), Levie, Corsica. Coll. and subm. 1966 by R. Grosjean.

Gif-796. Curacchiaghiu, Corsica 6

$7300 \pm 160$

Level $5,80 \mathrm{~cm}$ depth.

5350 в.C.

Gif-795. Curacchiaghiu, Corsica 5

$8560 \pm 170$

Level 5, $117 \mathrm{~cm}$ depth.

6610 B.C.

General Comment: dates arrival, maybe from N Africa, of a Neolithic culture with obsidian lithic industry and stamped and dotted ceramics (de Lanfranchi, 1967). Gives early date for apparition of ceramic in W Mediterranean.

Chaume de Montforgeon series, Courcelles-Fremoy, Côte d'Or

Charcoal from cinders and remains from ancient forge, at Chaume de Montforgeon, Courcelles-Fremoy (47 $26^{\prime} \mathrm{N}$ Lat, $4^{\circ} 10^{\prime} \mathrm{E}$ Long). Coll. by C. de la Roncière and subm. 1966 by A. Marelle, Fac. des Lettres et Sci. Humaines, Dakar.

Gif-734. Chaume de Montforgeon, No. 1

$830 \pm 90$

40 to $80 \mathrm{~cm}$ depth.

A.D. 1120

Gif-735. Chaume de Montforgeon, No. 2

$670 \pm 90$

$80 \mathrm{~cm}$ to $1 \mathrm{~m}$ depth.

A.D. 1280

General Comment: the 2 samples probably date same level.

\section{Chaume-les-Baigneux series, Côte d'Or}

Charcoal, in a barrow, at Chaume-les-Baigneux $\left(47^{\circ} 38^{\prime} \mathrm{N}\right.$ Lat, $4^{\circ}$ $34^{\prime}$ E Long), Côte d'Or. Coll. and subm. 1966 by R. Ratel, Fac. Sci., Dijon, Côte d'Or.

Gif-786. Chaume-les-Baigneux 1

From a hearth. 
Gif-1109. Chaume-les-Baigneux 2

Charcoal from incineration.

550 B.C.

General Comment: no archaeologic clue to date barrow. Belongs to Late Bronze age-Iron age limit.

\section{Gif-789. Minot, Côte d'Or}

$1670 \pm 100$ A.D. 280

Carbonized wood from Gallo-Roman villa, Ferme de Busserolles,

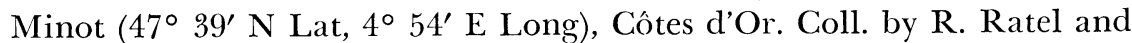
subm. 1967 by A. Joly, Circonscription des Antiquités Préhistoriques de Dijon. Comment: sample very well dated by archaeology at ca. 200 A.D. and used for calibration.

\section{Bressey series, Côte d'Or}

Different samples coll. at Bressey (47 $17^{\circ} \mathrm{N}$ Lat, 50 $11^{\prime} \mathrm{E}$ Long), Côte d'Or and subm. 1966, 1967 by R. Ratel.

Gif-727. Sablière de Bressey, 1

$2080 \pm 100$

Charcoal from refuse pit in Sablière de Bressey. Comment: assoc. ceramics typically from Hallstatt age. Too young.

\section{Gif-1090. Ferme de Clair Bois, Bressey}

$2000 \pm 100$

50 B.C.

Charcoal from incineration in barrow from Late Hallstatt, Ferme de Clair Bois, Bressey. Comment: confirms Gif-727 which dates a refuse pit situated some hundred $m$ from barrow.

\section{Gif-788. Sablière de Bressey, 2}

$10,200 \pm 230$

8250 B.C.

Wood from trunk of Pinus sylvestris, $3.50 \mathrm{~m}$ in sand, at la Sablière de Bressey. Comment: tree from same stratigraphic position as Sablière of Couternon, very close by, dated 9440 B.P. (Gif-34l, R., 1966, v. 8, p. 89).

\section{Gif-785. Neuvy-en-Dunois 66, Eure et Loir}

Carbonized human bones of 4 skeletons from collective sepulcher found in pit, covered by stones, at Neuvy-en-Dunois $\left(48^{\circ} 12^{\prime} \mathrm{N}\right.$ Lat, $1^{\circ} 33^{\prime}$ E Long) (Masset, 1968). Coll. and subm. 1966 by C. Masset, Paris. Comment: agrees with numerous dates already obtained in Brittany for collective sepulchers.

\section{Chaussée Tirancourt series, Somme}

Charcoal from rehandled part of large gallery grave containing remains of ca. 300 skeletons, La Chaussée Tirancourt $\left(49^{\circ} 58^{\prime} \mathrm{N}\right.$ Lat, $2^{\circ} 10^{\prime}$ E Long), Somme. Coll. and subm. 1968 by C. Masset. Sepulcher archaeologically dated from Chalcolithic age. Later on, large blocks of sandstone covering sepulcher were quarried away.

Gif-1289. La Chaussée Tirancourt, No. 1 
Gif-1372. La Chaussée Tirancourt, No. 3

$3700 \pm 120$

1750 B.C.

Gif-1378. La Chaussée Tirancourt, No. 4

$3650 \pm 120$

1700 B.c. General Comment: this extraction of sandstone began very soon after
the sepulcher.

$$
\text { B. Africa }
$$

\section{Gif-840. Tisoukai, Tassili n'Ajjer, Sahara}

$3650 \pm 130$

Charcoal from refuse layer, with Neolit and assoc with painting period, at Tisoukai $\left(9^{\circ} 30^{\prime} \mathrm{N}\right.$ Lat, 24 55' E Long), Tassili n'Ajjer, Sahara. Coll. and subm. 1967 by H. Lhote, Mus. de l'Homme, Paris. Comment: youngest date obtained for "Bovidian" period which lasted a few millennia.

\section{Gif-848. Zegag Oued, S Oran}

$5320 \pm 150$

Pearls from 9000 ostrich-eor pearls found with most undamaged, at Zegag Oued, near found with 55 Neolithic pots, Hammaguir, $S$ Oran $\left(30^{\circ} 49^{\prime}\right.$ correct age for a Neolithic site.

\section{Hassi Messaoud series, E Sahara}

Neolithic sites on oil field at Hassi-Messaoud $\left(32^{\circ} 00^{\prime} \mathrm{N}\right.$ Lat, $5^{\circ} 51^{\prime}$ E Long) E Sahara. Lithic material was studied by $\mathrm{H}$. Brezillon and $\mathrm{N}$. Chavaillon, palynology by F. Beucher. Subm. 1966 by H. Alimen, C.N.R.S., Bellevue.

\section{Gif-731. Hassi Messaoud, "La Touffe", $x$ o $\quad 5930 \pm 150$}

Coarse black sand with ash, Level III, $50 \mathrm{~cm}$ thick, $\mathbf{3 9 8 0}$ B.C. $\mathrm{cm}$. Some gramineae and abundant chenopodiaceae. Presence of fish, batrachia, and fresh-water mollusk indicate proximity of a stretch of water. Neolithic industry and ceramics of Capsian type.

\section{Gif-732. Hassi Messaoud, $\mathbf{x} 5$}

$6100 \pm 160$

Black sand with charcoal and shell fragments, depth: some $\mathrm{cm}$. Same industry as Gif-731.

\section{Gif-733. Hassi Messaoud, o Mn 17}

$$
5490 \pm 150
$$

Sandy black ground, $50 \mathrm{~cm}$ thick under yellow sand, $\mathbf{3 5 4 0}$ B.c. depression with flat bottom, diam ca $1 \mathrm{~km}$; probably sand, in a large , probably an ancient marsh. and -732 .

General Comment: may be evidence of evolution from Neolithic of Capsian tradition towards pure Saharian Neolithic. 


\section{Cave of Bitorri series, Brazzaville, Congo}

Samples from Cave of Bitorri, near village of Meya $\left(3^{\circ} 50^{\prime} \mathrm{S}\right.$ Lat, $14^{\circ} 30^{\prime}$ E Long), $150 \mathrm{~km} \mathrm{~N} \mathrm{~W} \mathrm{of} \mathrm{Brazzaville,} \mathrm{Congo} \mathrm{(Emphoux,} \mathrm{1970).}$ Coll. and subm. 1966 by J. P. Emphoux, O.R.S.T.O.M., Brazzaville.

Gif-459. Cave of Bitorri, 1

Charcoal from Level 17 , under $85 \mathrm{~cm}$ humic-rich layer with 20 archaeologic levels.

Gif-460. Cave of Bitorri, 2

Shells of gasteropods (kitchen-middens) from Level 14, $70 \mathrm{~cm}$ depth. Comment: as for Gif-459, presence of chipped flint implements. General Comment: dates late "Tshitolian" in Central Africa.

\section{Gif-851. Karkarichinkat, Tilemsi, Mali}

Human and animal bones from Neolithic site of Karkarichinkat, in Valley of Tilemsi ( $16^{\circ} 52^{\prime} \mathrm{N}$ Lat, $0^{\circ} 12^{\prime} \mathrm{E}$ Long), $80 \mathrm{~km} \mathrm{~N}$ Gao, Mali. Coll. 1962 by J. Gaussen and subm. 1967 by R. Mauny, Fac. des Lettres et Sci. Humaines, Paris. Karkarichinkat (Mauny, 1955), stretching on some hectares is a site with abundant Neolithic material: axes, heads of arrows, bone tools, ceramics, fauna, etc. (Gaussen and Gaussen, 1960); nearby are very big flint works. Comment: Neolithic age lasted till Iron age in W Africa; age is correct (Mauny et al., 1968).

\section{Chilca Canyon series, Peru}

$$
\text { C. Peru }
$$

Samples from different villages, in upper Chilca Canyon, central coast of Peru. Coll. and subm. 1967 by Frederic Engel, Univ. Nac. Agraria, Lima, Peru (Engel, 1964).

\section{Gif-864. Chilca Canyon, V. 2474}

$9700 \pm 200$

Willow-wood from pillar in a hut, Village $304\left(12^{\circ} 26^{\prime} \mathrm{S}\right.$ Lat, $76^{\circ}$ $46^{\prime}$ W Long). Comment: dates one of most ancient villages of coast of Peru.

Gif-1070. Chilea Canyon, V. 2411

$3210 \pm 110$

Burnt plant remains from Site 12 B-VII, Village $867\left(12^{\circ} 32^{\prime} \mathrm{S}\right.$ Lat, $76^{\circ} 41^{\prime}$ W Long). Comment (F.E.): dates one of large pre-agricultural villages in the "lomas" where food was based on a flora growing from the only atmospheric moisture.

Gif-1071. Chilca Canyon, V. 2417

$$
1100 \pm 100
$$

Vegetal debris in Site 12 B-VII, Level I, Village $868\left(12^{\circ} 31^{\prime} \mathrm{S}\right.$ Lat, $76^{\circ} 41^{\prime} \mathrm{W}$ Long). Comment: important village of maize consumers in gorge presently entirely dried up. 
Gif-1072. Chilca Canyon, V. 2444

Shells from Site 12 B-VII, Level I, Village 933 (120 $31^{\prime}$ I00 B.c. $38^{\prime}$ W Long), village of stony houses in the "lomas".

Gif-1296. Chilea Canyon, V. 2415

$6080 \pm 150$

4130 B.c. Site 12 B-VII, Village 908, Chiln from refuse, ash and shell deposit on Long), central coast of Peru.

\section{Gif-1297. Chilca Canyon, V. 2532}

$$
1420 \pm 100
$$

$29^{\prime}$ Cianonized vegetal remains from Site 12 B-VII, Village $2050\left(12^{\circ}\right.$ with semi-s $40^{\circ} \mathrm{W}$ Long), Chilca Canyon, central coast of Peru. Village ment (F F ): ment (F.E.): sample would help date start of potato culture in the village.

\section{Gif-1299. Chilca Canyon, V. 2665}

Wool cloth, Site 12 B-VII-12, village on left side of Chilca Canyon (12 $29^{\prime} \mathrm{S}$ Lat, $76^{\circ} 43^{\prime} \mathrm{W}$ Long). Comment: will help date some villages of "Cuculi" phase.

\section{Gif-1298. Bandurria, V. 2664}

$$
470 \pm 110
$$

A.D. 1480 Cotton cloth fragment from corpse buried at $1 \mathrm{~m}$ depth under refuse deposit, Site 12 B-VII-61, village of Bandurria (12 $30^{\prime} \mathrm{S}$ Lat, $76^{\circ} 46^{\prime}$ W Long). Coll. and subm. 1967 by F. Engel.

\section{Chavin de Huantar series}

Carbonized vegetal remains from Chavin de Huantar complex $\left(9^{\circ}\right.$ $35^{\prime} \mathrm{S}$ Lat, $77^{\circ} 10^{\prime} \mathrm{W}$ Long), alt $3200 \mathrm{~m}$, Peru. In this monument, signs of a new culture that arrived ca. 1600 B.c. in Peru, were defined and called "Chavin" culture. Coll. and subm. 1967 by F. Engel.

\section{Gif-1077. Chavin de Huantar, V. 2481}

$2370 \pm 100$ L. G. Lumbreras.

\section{Gif-1078. Chavin de Huantar, V. 2482}

$$
2730 \pm 110
$$

Site 8 D-X-I, Level 3 , in so-called “" 780 B.c. ceramics. Coll. by F. Caycho.

Gif-1079. Chavin de Huantar, V. 2483

$$
2100 \pm 100
$$

Site 8 D-X-I, Level 5 , in atrium of temple, covered by $\mathbf{1 5 0}$ B.c. by L. Gr. Lumbreras. Comment: dates reoccupation of by alluvia. Coll. parture of its builders. 
Gif-707. Bay of Paracas, V. 2335

$3845 \pm 200$

1895 B.c.

Human excrement from refuse deposit in a pit, covered by eolian sand, Site 14 A-VI-96, near Bay of Paracas, $265 \mathrm{~km} \mathrm{~S}$ of Lima $\left(13^{\circ} 5 \mathrm{l}^{\prime}\right.$ $\mathrm{S}$ Lat, $76^{\circ} 15^{\prime} \mathrm{W}$ Long). Alt. $+6 \mathrm{~m}$. Coll. and subm. 1966 by F. Engel. Comment: corresponds to Late Preceramic period with cotton, in middle $\mathrm{S}$ coast of Peru.

Gif-708. S of Lima, V. 2336

$4120 \pm 200$ 2170 B.C.

Human excrement from Site 12 B-VII, Village $613,58 \mathrm{~km} \mathrm{~S}$ of Lima $\left(12^{\circ} 25^{\prime} \mathrm{S}\right.$ Lat, $76^{\circ} 45^{\prime} \mathrm{W}$ Long), alt $200 \mathrm{~m}$. Found on ground of a "kiwa", an oval stony construction, half underground with 2 steps. Coll. and subm. 1966 by F. Engel. Comment: corresponds to last occupation of site during Preceramic period.

Gif-770. Perro Perdido, Supe Valley, V. 1654

$4735 \pm 140$

2785 B.c.

Charcoal from Site 10 A-VIII, II, Perro Perdido, Aspera peninsula, Supe valley $\left(10^{\circ} 49^{\prime} \mathrm{S}\right.$ Lat, $77^{\circ} 45^{\prime} \mathrm{W}$ Long), central coast of Peru. Coll. and subm. 1966 by F. Engel. Comment: preceramic site with cotton.

Gif-771. Bermejo, V. 1656

$2370 \pm 100$

420 B.c.

Cloth from Site 10 A-I-20 (I) I-2, at Bermejo (10 $34^{\prime}$ S Lat, $77^{\circ} 55^{\prime}$ W Long), Peru. Coll. and subm. 1966 by F. Engel. Comment: dates reutilization of a preceramic site during Chavin period.

$5175 \pm 200$

Gif-772. Paracas, V. 2450

3225 B.C.

Feathers found on corpse, in a grave, Site 14 A-VI, Village 96, Paracas Peninsula (13० 51 S Lat, $76^{\circ} 15^{\prime}$ W Long), S coast of Peru. Coll. and subm. 1966 by F. Engel.

Gif-1073. Quallikani, Puno, V. 2458

A.D. 1550

$400 \pm 90$

Straw used to temper raw bricks, in a funeral tower, Site 171-XI-2, Level I, Quallikani, Puno (16 $6^{\circ} 13^{\prime} \mathrm{S}$ Lat, $19^{\circ} 54^{\prime} \mathrm{W}$ Long), alt $4000 \mathrm{~m}$. Coll. and subm. 1967 by F. Engel.

Gif-1074. Cave of Jankulloni, Puno, V. 2461

$2890 \pm 110$

940 в.c.

Carbonized plants from cave of Jankulloni, Site 18 F-II-I, Level 3 (16 ${ }^{\circ} 29^{\prime} \mathrm{S}$ Lat, $69^{\circ} 22^{\prime}$ W Long), Pisacoma dist., Puno, alt $4000 \mathrm{~m}$. Coll. and subm. 1967 by F. Engel. Comment: deepest level of site; assoc. with lithic industry.

Gif-1076. Kampa, Puno, V. 2466

$2700 \pm 110$

750 в.C.

Burnt plants from Rock-shelter I of Kampa, Site 171-XI-I, Level 2, (16 $46^{\circ} \mathrm{S}$ Lat, $69^{\circ} 59^{\prime} \mathrm{W}$ Long), Pisacoma dist., Puno, alt $4100 \mathrm{~m}$. 
Coll. and subm. 1967 by F. Engel. Comment: dates occupational period of shelter with walls decorated by paintings.

\section{Miscellaneous Countries}

\section{Gif-1247. Arta, $2900 \pm 110$ \\ C.P. S.P. 950 в.c.}

Charcoal from burning level, $90 \mathrm{~cm}$ depth, from House 12, Arta $\left(39^{\circ} 41^{\prime} \mathrm{N}\right.$ Lat, $3^{\circ} 21^{\prime} \mathrm{E}$ Long). Coll. by G. Lilliu and subm. 1968 by R. Grosjean. Comment: interesting for chronologic comparison between similar civilizations: Talyotic in Balearic Is., Nuragic in Sardinia and Torre civilizations in Corsica.

\section{Mallia series, Kriti}

Charcoal from Mallia $\left(37^{\circ} 17^{\prime} \mathrm{N}\right.$ Lat, $25^{\circ} 27^{\prime} \mathrm{E}$ Long, Kriti.

\section{Gif-447. Mallia 1}

$3800 \pm 200$

and close coul Française d'Athènes.

\section{Gif-448. Mallia 2}

$3905 \pm 200$

Carbonized wood, $80 \mathrm{~cm}$ depth, in destruction layer. Coll. and subm. 1966 by J. C. Poursat.

\section{Gif-449. Mallia 3}

Charcoal, $80 \mathrm{~cm}$ depth, at surface of thick layer of and subm. 1966 by J. C. Poursat. Comment: date is too young.

Gif-874. Mallia 4

$3350 \pm 120$

Charcoal, $2.80 \mathrm{~m}$ depth. Coll. and subm. 1967 by J. C. Poursat.

\section{Gif-875. Mallia 5}

$3780 \pm 130$

Carbonized wood from a cypress pillar, $90 \mathrm{~cm}$ depth, same house as Mallia 4. Coll. and subm. 1967 by J. C. Poursat.

\section{Gif-1277. Mallia 7}

$3380 \pm 110$

1430 в.c.

Charcoal from destruction layer of the "Petit Palais," 0.50 to $1 \mathrm{~m}$ depth, $1 \mathrm{~m}$ thick. Coll. and subm. 1968 by O. Pelon, Ecole Française d'Athènes.

\section{Gif-1279. Mallia 6}

Charcoal, $1 \mathrm{~m}$ depth, under a close course of bricks. Coll. and subm. 1968 by J. G. Poursat. 
Gif-1521. Mallia 8

$3100 \pm 110$

1150 B.c.

Charcoal, from destruction layer of the "Petit Palais." Coll. and subm. 1968 by O. Pelon.

\section{Mari series, Moyen Euphrate}

Samples from palaces of Mari, in Mesopotamia (34 $29^{\prime} \mathrm{N}$ Lat, $40^{\circ}$ $56^{\prime}$ E Long). Archaeologically well situated in 1st half of 3rd millennium B.c. Coll. 1965 and subm. 1966 by A. Parrot, Archaeol. Mission in Mari.

Gif-496. Mari 1

$4100 \pm 150$

Fragment of wood from beams of presargonic palace in Mari.

\section{B.C.}

Gif-497. Mari 2

$4075 \pm 150$

Similar to Gif-496.

2125 B.C.

Gif-498. Mari 3

$4040 \pm 150$

Similar to Gif-496.

2090 B.c.

Gif-721. Mari 6

$4000 \pm 150$

2050 B.c. in Mari.

Fragment of wood from beams from podium of presargonic palace

Gif-722. Mari 4

$3820 \pm 120$

1870 B.C.

Carbonized wood in central Jar I, Rm. 219, palace in Mari.

\section{Gif-723. Mari 5}

$3720 \pm 150$

1770 B.C. Mari.

Carbonized wood and corns in central Jar 2, Rm. 219, palace in

General Comment: chronology places level dated by Gif-496, -498 and Gif-727 between 2700 and 2400 B.C. $\mathrm{C}^{14}$ dates are at least $400 \mathrm{yr}$ too young. But Gif-722 and -723 come from a palace burnt very probably in 1760 B.C.; $\mathrm{C}^{14}$ dates are, thus, very coherent with archaeologic data.

II. GEOLOGIC AND PALYNOLOGIC SAMPLES

\section{A. France}

1. W. France

Gif-709. Plage de Corréjou,

Plouguerneau, Finistère

$935 \pm 100$

A.D. 1015

Peat under sand hill, on beach of Corréjou, Plouguerneau $\left(48^{\circ} 38^{\prime}\right.$ N Lat, $4^{\circ} 30^{\prime} \mathrm{W}$ Long). Coll. and subm. 1966 by M. T. Morzadec, Lab. Geol. Fac. Sci., Rennes. Comment: disagreement with pollen analysis; contaminated by rootlets of present vegetation; base level of the peat bog, $1 \mathrm{~m}$ deeper, was found $4250 \mathrm{yr}$ old (Gif-282, R., 1966, v. 8, p. 78; Morzadec, 1969). 


\section{Gif-712. Lampaul-Plouarzel, Finistère}

Salt marsh peat from base level of

Plouarzel $\left(48^{\circ} 28^{\prime} \mathrm{N}\right.$ Lat, $4^{\circ} 46^{\prime}$ W sea level Coll and subm 1966 Long), Finistère, $3.50 \mathrm{~m}$ above mean sea level. Coll. and subm. 1966 by M. T. Morzadec. Comment: Pollen Zone: VII b-VIII transition. Presence of hystrichospheres, at base level only, indicates site was close to seashore, at that time.

\section{Gif-713. Le Scluz, Brignogan, Finistère}

$$
1260 \pm 100
$$

Submerged peat bog on strand, Le Scluz, Brignogan $\left(48^{\circ} 41^{\prime} \mathrm{N}\right.$ Lat, $4^{\circ} 20^{\prime} \mathrm{W}$ Long) $2.50 \mathrm{~m}$ above mean sea level. Coll. and subm. by M. T. Morzadec. Comment: Pollen Zone VII b; certainly contaminated.

\section{Gif-714. Trezien, Plouarzel, Finistère}

$3660 \pm 115$

Fresh water peat on 1710 B.c.

$47^{\prime} \mathrm{W}$ Long), Finistère $47^{\prime} \mathrm{W}$ Long), Finistère. Coll. and subm. 1966 by M. T. Morzadec; 1.50 $\mathrm{m}$ above mean sea level. Pollen Zone: VII $\mathrm{b}$.

\section{Gif-818. Santec, Finistère}

$$
2330 \pm 105
$$

Salty peat, ca. $2 \mathrm{~m}$ above $\mathrm{m} . \mathrm{s}, \mathrm{l}$, $43^{\prime} \mathrm{N}$ Lat, $4^{\circ} 02^{\prime} \mathrm{W}$. $43^{\prime} \mathrm{N}$ Lat, $4^{\circ} 02^{\prime} \mathrm{W}$ Long), Finistère. Coll. and subm. 1967 by M. T. Morzadec. Comment: pollen analysis: Sub-Atlantic, Zone VIII.

\section{Landunvez series, Finistère}

Salty peat bog on shore, Gwen-Trez, Landunvez $\left(48^{\circ} 32^{\prime} \mathrm{N}\right.$ Lat, $4^{\circ} 48^{\prime} \mathrm{W}$ Long), N Argenton, Finistère. Coll. and subm. 1967 by M. T.
Morzadec.

\section{Gif-815. Landunvez 1}

Ca. m.s.l. Comment: pollen analysis: Sub-Boreal-Sub-Atlantic transition, VII b-VIII, or just under.

Gif-816. Landunvez 2

$0.50 \mathrm{~m}$ under m.s.l. Zone VII b.

\section{Gif-817. Landunvez 3}

\section{Ploulec'h series, Côtes du Nord}

Peat dredged in estuary of Lannion R., Ploulec'h $\left(48^{\circ} 44^{\prime} \mathrm{N}\right.$ Lat, $3^{\circ} 32^{\prime} \mathrm{W}$ Long), Côtes du Nord. Coll. and subm. 1967 by P. R. Giot and M. T. Morzadec.

\section{Gif-819. Ploulec'h 1}

$3075 \pm 110$

Comment: 2 swords were dredgedt at 1125 B.c. to an ancient ford. 


$$
1600 \pm 105
$$

\section{Gif-820. Ploulec'h 2} bed.

Comment: many Roman antiquities are found in this ancient river General Comment: agree well with archaeologic frequentation of the site. Both Zone VIII, Sub-Atlantic.

\section{Porsguen series, Plouescat, Finistère}

Submerged peat bog on strand, Porsguen Beach, Plouescat $\left(48^{\circ} 41^{\prime}\right.$ N Lat, $4^{\circ} 13^{\prime}$ W Long), Finistère. Coll. and subm. 1966 by M. T. Morzadec. Pollen Zone: VIIa-VIIb.

\section{Gif-710. Porsguen, Plouescat 1}

Peaty silt, $+2.50 \mathrm{~m}$ bovea m.s.l. Comment: many sherds of Bronze age pottery were found in this level. Transition Zone VIIb-VIII.

\section{Gif-711. Porsguen, Plouescat 2}

$$
4120 \pm 140
$$

Wood and charred wood from peaty level, $+2.00 \mathrm{~m}$ above m.s.l. Comment: presence of hystrichospheres. Zone VIIb.

\section{Gif-891. Pointe de la Torche, Plomeur, Finistère}

$$
1100 \pm 90
$$

\section{A.D. 850}

Shells in sandy layer, with gravel, ca. $+2 \mathrm{~m}$ above sea level, at Pointe de la Torche, Plomeur (44 $31^{\prime} \mathrm{N}$ Lat, $4^{\circ} 22^{\prime} \mathrm{W}$ Long), Finistère. Coll. and subm. 1967 by P. R. Giot and A. Guilcher, Fac. des Lettres, Brest. Comment: a 1st sample from another level at another point was dated in 1963,580 B.P. (Gif-238, R., 1966, v. 8, p. 77). Both corroborate existence of very recent sea levels at this place, as expected.

\section{Gif-1100. La Torche, Plomeur, Finistère}

$2670 \pm 110$

720 B.C.

Debris of shells from a lumachelle, $1 \mathrm{~m}$ thick, on strand, at low tide sea level, N La Torche, Baie d'Audierne (47 $32^{\prime}$ N Lat, $4^{\circ} 22^{\prime}$ W Long). Coll. and subm. 1967 by A. Guilcher and P. R. Giot.

\section{Gif-850. Off S. Pointe de Penmarc'h}

$$
10,200 \pm 230
$$

Shells (Cyprina Islandica) dredged in place, between 110 and 120 cm depth, in muddy sediments called "La Grande Vasière", on continental shelf, $45 \mathrm{~km}$ off $\mathrm{S}$. Pointe de Penmarc'h $\left(47^{\circ} 20^{\prime} \mathrm{N}\right.$ Lat, $4^{\circ} 32^{\prime}$ W Long). Coll. and subm. by M. Glemarec, Fac. Sci., Brest. Comment: this shell species, at present, occurs only $\mathrm{N}$ of $52^{\circ} \mathrm{N}$ Lat; its presence confirms cold water, S of Bretagne 10,000 yr ago (Glemarec, 1969).

\section{Gif-849. Off estuary of Loire}

Shells (Glycymeris) dredged at $40 \mathrm{~m}$ depth, in Atlantic Ocean, off estuary of Loire $\left(47^{\circ} 00^{\prime} \mathrm{N}\right.$ Lat, $2^{\circ} 40^{\prime} \mathrm{W}$ Long). Lying on surface sediment, probably not in situ. Coll. and subm. 1967 by M. Glemarec. Com- 
ment: expected to prove fossil species; different varieties of Glycymeris, both fossil and living, were found later on this part of continental shelf.

Gif-876. Loire estuary

$4300 \pm 140$

Wood from a big trunk, 12 to 1

Nepth, from bank of Loire, at Nantes (47 $14^{\prime} \mathrm{N}$ Lat, $1^{\circ} 35^{\prime} \mathrm{W}$ Long). Subm. 1967 by F. Ottman, Fac. Sci., Nantes. Comment: rate of sedimentation in Loire estuary calculated 3 to $4 \mathrm{~mm} / \mathrm{yr}$, coherent with other estimates.

\section{Gif-839. Saint-Lumine de Coutais, Loire Atlantique}

Peat, in a drowned peat bog, 125 to $137 \mathrm{~cm}$ depth, at Saint-Lumine de Coutais $\left(47^{\circ} 04^{\prime} \mathrm{N}\right.$ Lat, $3^{\circ} 02^{\prime} \mathrm{W}$ Long). Coll. 1966 and subm. 1967 by N. Planchais. Comment: subm. because of abundance of vine pollen at this level, but systematic pollen analysis in region also indicated important mixing of sediments, probably due to a tide-race which devastated country at end of 6th century.

\section{Asnelles series, Calvados}

Three borings were made in Quaternary formations, along the coast, at Asnelles, $\left(49^{\circ} 20^{\prime} \mathrm{N}\right.$ Lat, $0^{\circ} 34^{\prime} \mathrm{W}$ Long), Calvados. The 1st one, on the strand, the 2nd, at the top of the beach, $130 \mathrm{~m}$ from the 1st and, the $3 \mathrm{rd}$ in the marsh behind shoestring sands, ca. $70 \mathrm{~m} \mathrm{SE}$ of the preceding one. At the bottom, is sandy gravel, becoming finer and then silty with organic remains; peat overlies silty sand. On the top, in Borings 2 and 3, are either brackish or marine sediments, which are probably eroded in Boring 1. Alt of borings relative to m.s.l. is $+0.3 \mathrm{~m}$ for Boring $1,+2.65 \mathrm{~m}$ for Boring 2, and $+3.20 \mathrm{~m}$ for Boring 3. Peat or peaty silt were coll. and subm. 1967, 1968 by C. Larsonneur, Fac. Sci., Caen, Calvados. Palynologic study was done by H. Elhai. Depths are given from top of the core.

Gif-1009. Asnelles, Boring 1, As 9

$7000 \pm 170$ 250 and As 13: $8320 \pm 200$ (R., 1969, v. 11, p. 329).

Gif-1012. Asnelles, Boring 1, As 23

$11,450 \pm 270$ 9500 B.c.

$210 \mathrm{~cm}$ depth, base level of peat bog. Comment: according to pollen analysis, would correspond to Alleröd.

Gif-1013. Asnelles, Boring 2, As 34 $83 \mathrm{~cm}$ depth.

$3950 \pm 140$ 2000 B.c.

Gif-1014. Asnelles, Boring 2, As 36 $5650 \pm 150$ $105 \mathrm{~cm}$ depth. 3700 B.c. 
Gif-1015. Asnelles, Boring 2, As 38 $7450 \pm 150$ $126 \mathrm{~cm}$ depth.

Gif-1016. Asnelles, Boring 2, As 39 $160 \mathrm{~cm}$ depth.

Gif-1017. Asnelles, Boring 2, As 40

Gif-1176. Asnelles, Boring 3, As 51 $50 \mathrm{~cm}$ depth.

Gif-1177. Asnelles, Boring 3, As 53 $70 \mathrm{~cm}$ depth.

Gif-1178. Asnelles, Boring 3, As 56 $110 \mathrm{~cm}$ depth.

Gif-1179. Asnelles, Boring 3, As 58 $150 \mathrm{~cm}$ depth.

Gif-1180. Asnelles, Boring 3, As 64 5500 B.c.

$8700 \pm 250$ 6750 B.C.

$200 \mathrm{~cm}$ depth.

General Comment: good correlation with pollen analysis for the 3 cores. Peat bog was formed while sea was still very low, hence depths cannot be related to former sea level. It is only during the Sub-Boreal that influence of the sea is seen (presence of Chenopodiaceae); by that time sea level was very near the present.

Peat formation was particularly rapid during the Boreal period $(10 \mathrm{~cm} / 100 \mathrm{yr})$ and from the end of Atlantic to Sub-Boreal period (5700 to 2700 в.P.) (Delibrias et al., 1969).

\section{Cherbourg harbor series, Manche}

Submerged peat from borings, off Cherbourg. Subm. 1968 by C. Larsonneur. Depths related to m.s.l.

Gif-1020. Cherbourg, $121 \mathrm{C}$

$4950 \pm 140$

In Becquet bay $\left(49^{\circ} 40^{\prime} \mathrm{N}\right.$ Lat, $1^{\circ} 32^{\prime} \mathrm{W}$ Long). Depth: $34.60 \mathrm{~m}$. Comment: very young for such depth.

Gif-1021. Cherbourg, $128 \mathrm{C}$

$9470 \pm 130$ 7520 B.c.

In Becquet bay $\left(49^{\circ} 41^{\prime} \mathrm{N}\right.$ Lat, $1^{\circ} 33^{\prime} \mathrm{W}$ Long). Depth: $34.40 \mathrm{~m}$.

Gif-1022. Cherbourg, $215 \mathrm{C}$

$8200 \pm 190$ 6250 B.c.

In outer roadstead ( $49^{\circ} 40^{\prime} \mathrm{N}$ Lat, $1^{\circ} 37^{\prime} \mathrm{W}$ Long). Depth: $29.10 \mathrm{~m}$. 
Gif-1023. Cherbourg, 235 C

$9880 \pm 230$

7930 B.c.

In outer roadstead $\left(49^{\circ} 40^{\prime} \mathrm{N}\right.$ Lat, $1^{\circ} 37^{\prime} \mathrm{W}$ Long). Depth: $22.90 \mathrm{~m}$. General Comment: interesting for studying variations of sea level (Delibrias and Guillier, in press).

\section{Le Havre series, Channel}

Peat from sediment cores taken off Le Havre preparatory to construction of a relay-port for super-tankers. Subm. 1966, 1967 by J. P. Michel, Fac. Sci., Paris; P. Larsonneur and M. Guyader, Dir. Autonomous Harbour, Le Havre. Depths related to m.s.l.

Gif-744. Core 289

$26.75 \mathrm{~m}\left(49^{\circ} 30^{\prime} \mathrm{N}\right.$ Lat, $0^{\circ} 06^{\prime} \mathrm{E}$ Long).

Gif-745. Core 287 bis

$27.40 \mathrm{~m}\left(49^{\circ} 30^{\prime} \mathrm{N}\right.$ Lat, $0^{\circ} 06^{\prime} \mathrm{E}$ Long).

Gif-746. Core 284

$27.70 \mathrm{~m}\left(49^{\circ} 30^{\prime} \mathrm{N}\right.$ Lat, $0^{\circ} 06^{\prime} \mathrm{E}$ Long).

\section{Gif-1019. Core 9 H}

$19.50 \mathrm{~m}\left(49^{\circ} 28^{\prime} \mathrm{N}\right.$ Lat, $0^{\circ} 17^{\prime} \mathrm{W}$ Long).

Gif-1238. Core $\mathrm{X}$

$29 \mathrm{~m}\left(49^{\circ} 28^{\prime} \mathrm{N}\right.$ Lat, $0^{\circ} 17^{\prime} \mathrm{W}$ Long).

\section{Gif-1401. Core 804}

$21.5 \mathrm{~m}$ to $22.7 \mathrm{~m}\left(49^{\circ} 28^{\prime} \mathrm{N}\right.$ Lat, $0^{\circ} 17^{\prime} \mathrm{W}$ Long $)$.

General Comment: agrees well with pollen analysis (Michel, 1968). Interesting for studying variation of sea level.

\section{Gif-1067. Saint Sauveur de Pierrepont Manche} boring at Saint Sauveur de Pierrepont $\left(48^{\circ} 37^{\prime} \mathrm{N}\right.$ Lat, $1^{\circ} 36^{\prime} \mathrm{W}$ Long), Manche. Ca. $-6.40 \mathrm{~m}$ related to m.s.l. Coll. and subm. 1967 by C. Pareyn, Fac. Sci., Caen. Comment: impossible to interpret shell bed as old beach.

\section{Gif-1110. Mammoth tooth, Channel}

$19,300 \pm 700$

Collagen from mammoth tooth from Channel, ca. $60 \mathrm{~m}$ depth $\left(50^{\circ}\right.$ $27^{\prime} \mathrm{N}$ Lat, $0^{\circ} 25^{\prime} \mathrm{W}$ Long), from site of numerous mammoth remains. Subm. 1967 by C. Larsonneur. Comment: from same site as Sa-342 (8720 \pm 300 , R., 1966, v. 8 , p. 90), of which total carbon (not only collagen) was extracted for dating. 
2. N. and Central France

\section{Marquenterre series, Picardie}

Peaty samples from Sec. $M 21$, in peat bog, at Marquenterre $\left(50^{\circ}\right.$ $16^{\prime} \mathrm{N}$ Lat, $1^{\circ} 42^{\prime} \mathrm{E}$ Long), in maritime plain of Picardie. Alt $+4 \mathrm{~m}$. Coll. and subm. 1967 by P. Lefevre, Stat. d'Agronomie, Amiens. Pollen analysis by N. Planchais.

Gif-841. Marquenterre, $100 \mathrm{~cm}$ A.D. 970

Sandy brown peat.

$$
3060 \pm 110
$$

Gif-842. Marquenterre, 440 to $460 \mathrm{~cm}$ 1110 B.C.

Brown peat with vegetal remains. Pollen zone: late appearance of Fagus; Sub-Atlantic.

Gif-843. Marquenterre, 580 to $600 \mathrm{~cm}$

$5080 \pm 140$

3130 B.C.

Brown peat, with lighter zones. Pollen zone: Atlantic-Sub-Boreal transition.

Gif-844. Marquenterre, 640 to $660 \mathrm{~cm}$

$\mathbf{5 5 2 0} \pm \mathbf{1 5 0}$

Brown peat with shells of small gastropods. 3570 B.C.

\section{Gif-845. Marquenterre, 660 to $670 \mathrm{~cm}$}

$6450 \pm 160$

4500 B.C.

Brown peat with sandy appearance. Pollen zone: Atlantic period with Quercus, Titiolum, Ulmus, and Alnus dominant.

General Comment: dates stages of formation of coastal plain of Picardie.

\section{Gif-836. Mur de Sologne, Loiret}

$7800 \pm 190$

$\mathbf{5 8 5 0}$ B.C.

Silty peat, level 2.62 to $2.75 \mathrm{~m}$, in peat bog near Mur de Sologne $\left(47^{\circ} 25^{\prime} \mathrm{N}\right.$ Lat, $0^{\circ} 36^{\prime} \mathrm{E}$ Long). Coll. 1966 and subm. 1967 by $\mathrm{N}$. Planchais, Fac. Sci., Montpellier. Comment: pollen diagram shows frequencies of Pinus and Betula, rise of Corylus, and beginning of Ulmus. Corrects age, which was too young, for Sa-235 (R., 1965, v. 7, p. 24l) from same level but probably contaminated. Beginning of Boreal.

\section{Rians series, Cher}

Peat from bog, Rians (47 $09^{\prime} \mathrm{N}$ Lat, $0^{\circ} 15^{\prime} \mathrm{E}$ Long), Cher. Coll. 1966 and subm. 1967 by N. Planchais.

Gif-837. Rians, $0.70 \mathrm{~m}$ depth

$3970 \pm 140$ 2020 B.C.

Pollen zone: Quercus, Tilia, just before beginning of Fagus. Beginning of Sub-Atlantic.

Gif-838. Rians, 1.10 to $1.40 \mathrm{~m}$

$6630 \pm 170$ 4680 в.c.

Pollen zone: Quercus and Ulmus abundant, Tilia at low frequency and Fraxinus at beginning. Indicates Boreal-Atlantic boundary. 


\section{Mont de l'Espinouse series, Cévennes}

Sphagnum peat bogs, lying on gneiss bedrock, from S limit of Massif Central, in Mont de l'Espinouse, Cévennes. Coll. and subm. 1967 by A. Pons, Fac. Sci., Marseille.

Gif-1101. La Salverguette

A.D. 1100

$75 \mathrm{~cm}$ depth, (43 $38^{\prime} \mathrm{N}$ Lat, $2^{\circ} 54^{\prime}$ E Long), alt: $1070 \mathrm{~m}$.

\section{Gif-1102. La Salverguette}

$100 \mathrm{~cm}$ depth, base level.
$1140 \pm 100$

A.D. 810

$350 \pm 95$

A.D. 1600

Gif-1103. Font-Salesse

$65 \mathrm{~cm}$ depth, base level (43 $36^{\prime} \mathrm{N}$ Lat, $2^{\circ} 58^{\prime} \mathrm{E}$ Long), alt: $1060 \mathrm{~m}$.

\section{Gif-1104. Baissescure}

$6000 \pm 150$

$140 \mathrm{~cm}$ depth, base level with silt, $\left(43^{\circ} 32^{\prime} \mathrm{N}\right.$ Lat, $2^{\circ} 48^{\prime} \mathrm{E}$ Long), alt: $1000 \mathrm{~m}$.

General Comment: except for Gif-1104, which is dated from Boreal, ages found are surprising and tend to cast doubt on accepted inferences from pollen analysis in this region. This is probably due to geography of region, subject both to Mediterranean and Atlantic influences. Pollen study by de Beaulieu (1969).

\section{S. E. and S. W. France}

Gif-1129. La Flachère, Isère

Black lignite with fragments of wood in clay under fluvial facies of alluvia and glacial sand, at La Flachère $\left(45^{\circ} 24^{\prime} \mathrm{N}\right.$ Lat, $5^{\circ} 58^{\prime} \mathrm{E}$ Long), Isère valley. Coll. and subm. 1968 by G. Montjuvent, Fac. Sci., Grenoble. Comment: as expected.

Gif-1130. Bruant, Isère

Debris of branches in local moraine of Vercors, Bruant $\left(45^{\circ} 01^{\prime} \mathrm{N}\right.$ Lat, 5 $5^{\circ} 37^{\prime}$ E Long), Isère. Coll. and subm. 1968 by G. Montjuvent. Comment: question was whether this moraine was built recently by local glaciers.

\section{Gif-824. Plateau de la Matheysine, Savoie}

$9830 \pm 230$

Submerged peat, from bank of Lac Mort, on Plateau de la Mathey. sine ( $45^{\circ} 02^{\prime} \mathrm{N}$ Lat, $5^{\circ} 47^{\prime} \mathrm{E}$ Long), S E Grenoble. Coll. and subm. 1967 by G. Montjuvent. Plateau is a glacial valley, alt: $900 \mathrm{~m}$. During the Würm it was occupied by 2 glacier tongues; the Romanche tongue, at the $\mathrm{N}$, built a series of frontal moraines which now delimit 4 dammed lakes; one is Lac Mort. Age of peat implies that glacier evacuated the valley ca. 10,000 B.P. 


\section{Gif-825. Trièves, Savoie}

Fossil wood in calcareous and marly material transported in a landslide over Würm moraine (44 $47^{\prime} \mathrm{N}$ Lat, $5^{\circ} 44^{\prime} \mathrm{E}$ Long). Coll. and subm. 1967 by G. Montjuvent. Comment: corrects geologic map on which these sediments were shown as post-Würm alluvium.

\section{Lac de Balcère series, Pyrénées Orientales}

Peat from submerged peat bog of Lac de Balcère $\left(42^{\circ} 35^{\prime} \mathrm{N}\right.$ Lat, $2^{\circ}$ 03' E Long), Pyrénées Orientales; alt: $1764 \mathrm{~m}$. Coll. and subm. 1967 by C. Jalut, Lab. de Botanique, Fac. Sci., Toulouse.

$3780 \pm 135$

Gif-1060. Lac de Balcère, Palyn 6

$$
1730 \text { в.c. }
$$

$0.50 \mathrm{~m}$ to $0.60 \mathrm{~m}$ depth. Pollen analysis: Zone VII b of Sub-Boreal period. Comment: too young; superficial levels probably slightly contaminated.

Gif-791. Lac de Balcère, Palyn 1

$9250 \pm 210$

$1.50 \mathrm{~m}$ to $1.60 \mathrm{~m}$ depth. Pollen analysis: appearance of Abies; end of Pre-Boreal period. Comment: date in good agreement.

\section{Gif-792. Lac de Balcère, Palyn 2}

$11,240 \pm 280$

9290 B.C.

$2.60 \mathrm{~m}$ to $2.70 \mathrm{~m}$ depth. Pollen analysis: Zone II of Alleröd. Comment: in good agreement.

General Comment: aids study of evolution of flora from Early Dryas to Sub-Atlantic. Alleröd oscillation is shown for 1st time in Pyrénées Orientales (Van Campo and Jalut, 1969).

\section{Mas de la Borde series, Pyrénées Orientales}

Peat bog, in Valley of Têt, Mas de la Borde $\left(42^{\circ} 32^{\prime} \mathrm{N}\right.$ Lat, $2^{\circ} 05^{\prime}$ E Long), alt: $1680 \mathrm{~m}$, Pyrénées Orientales. Coll. and subm. 1967 by G. Jalut.

\section{Gif-868. Mas de la Borde, Palyn 3}

$0.70 \mathrm{~m}$ to $0.80 \mathrm{~m}$ depth; from surface to $0.60 \mathrm{~m}$ depth, ploughed soil overlies peat bog with sharp contact. Pollen analysis indicates beginning of cultivation.

Gif-869. Mas de la Borde, Palyn 4 $7500 \pm 170$ 5550 B.c.

$2.30 \mathrm{~m}$ to $2.40 \mathrm{~m}$ depth. Pollen analysis: extension of Abies. Comment: in good agreement.

Gif-870. Mas de la Borde, Palyn 5

$8300 \pm 190$

$3.50 \mathrm{~m}$ to $3.60 \mathrm{~m}$ depth.

General Comment: Abies is dated here at 7500 B.P. whereas it is dated 
at 9250 B.P. at Lac de Balcère; these 2 peat bogs, some $\mathrm{km}$ apart, have very different exposures, which can explain age difference.

\section{Gurp series, Médoc}

Fossil soils in cliff of Gurp $\left(45^{\circ} 26^{\prime} \mathrm{N}\right.$ Lat, $1^{\circ} 08^{\prime} \mathrm{W}$ Lat), Médoc. Coll. and subm. 1967 by P. Dutil, Sta. Agron., Châlons-sur-Marne.

\section{Gif-1032. Gurp, G. U. Paleosol}

$3300 \pm 120$

Black organic horizon, $\mathrm{A}_{0} \mathrm{~A}_{1}$, of a Podzol under a dune, 150 to $170 \mathrm{~cm}$ below top of cliff. Comment: iron hardpan was without carbon; age similar to other Podzols in region.

Gif-1105. Gurp, G. U., wood

Wood from lignite, from foot of cliff, $340 \mathrm{~cm}$ depth, just above blue gray silt. Comment: too old to be dated by $\mathrm{C}^{14}$, as expected.

\section{Mediterranean}

\section{Gif-738. Shoal of Méjean}

Polyparies, $3.90 \mathrm{~m}$ below surface; in sediment core C.A.P.P. 58, at

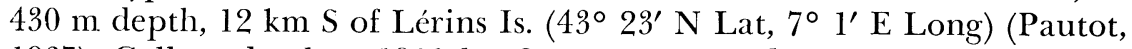
1967). Coll. and subm. 1966 by G. Pautot, Sta. de Géodynamique sousmarine, Villefranche-sur-Mer, Alpes Maritimes. Comment: agrees with known sedimentation rates in W Mediterranean Sea (Labeyrie et al., 1968).

Gif-829. Little Submarine Canyon of Planier

Chlamys septemradiatus, $24 \mathrm{~km}$ off Cap Couronne, $170 \mathrm{~m}$ depth in the little Canyon of Planier ( $43^{\circ} 34^{\prime} \mathrm{N}$ Lat, $5^{\circ} 05^{\prime} \mathrm{E}$ Long), Mediterranean. Dredged during Mission Calypso 1966 and subm. 1967 by L. Dangeard, Fac. Sci., Caen. Comment: Chlamys septemradiatus is characteristic of cold water.

Gif-828. Living Chlamys, Marseille

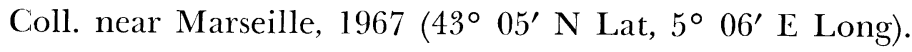

\section{Tchad series}

$$
\text { B. Africa }
$$

In low regions of Tchad, between 13th and 17th parallel, 2 lithostratigraphic units may be distinguished: (1) Soulias series forms sandy bars with layers of clay and marl with Ostracods in interdune depression. (2) Labdé series is lacustrine, clayey and diatomaceous, or calcareous, 10 to $15 \mathrm{~m}$ thick, in which 2 lacustrine extensions can be distinguished: $1_{1}$ and $1_{2}$ (Servant et al., 1969). Samples coll. and subm. 1966-1968 by M. Servant. Office de la Recherche Sci. des Territoires d'Outre Mer (O.R.S.T.O.M.), Fort-Lamy, Tchad.

\section{Gif-799. Amakha, Tchad, S-805}

Mollusk shells, $1 \mathrm{~km} \mathrm{~S}$ of well of Amakha (13० $51^{\prime} \mathrm{N}$ Lat, $15^{\circ} 28^{\prime}$

E Long), Tchad, in sandy silt with calcareous concretions, $5 \mathrm{~m}$ above 
Bahr-el-Ghazal. Comment: top of recent alluvium of base of Bahr-elGhazal.

\section{Gif-1096. Nedeley, Tchad, S-1106}

Pila shells in sandstone at top alluvium of floor of Bahr-el-Ghazal, 1 $\mathrm{km} \mathrm{E}$ of Nedeley well (15 $36^{\prime} \mathrm{N}$ Lat, $18^{\circ} 09^{\prime} \mathrm{E}$ Long), Tchad. Comment: base at Bahr-el-Ghazal was marshy at very recent period; assoc. with elephant and hippopotamus.

Gif-1099. Kosomanga, Tchad, S-1426

$1750 \pm 100$

Bulinus shells in interdune depression at Kosomanga $\left(14^{\circ} 02^{\prime} \mathrm{N}\right.$ Lat, $16^{\circ} 03^{\prime} \mathrm{E}$ Long), Tchad. Comment: confirms existence of moist pulsation in Tchad ca. 1800 B.P. Sequence $1_{2}$ of Labdé.

Gif-798. Well of Salal, Tchad, S-731

Peaty silt in a well of Salal (14 $50^{\prime} \mathrm{N}$ Lat, $17^{\circ} 13^{\prime} \mathrm{E}$ Long), 11.60 $\mathrm{m}$ depth at base of lacustrine silt. Comment: base of alluvium of Bahrel-Ghazal.

Gif-797. Ebeta, Tehad, S-485

$2450 \pm 110$ 500 B.c.

Tufa with Phragmites from upper part of lacustrine sediment, $1 \mathrm{~m}$ thick, in 1 unterdune depression, Ebeta (13 $48^{\prime} \mathrm{N}$ Lat, $15^{\circ} 42^{\prime} \mathrm{E}$ Long). Comment: dates end of a wet period, 2nd sequence of lacustrine Labdé series, $1_{2}$.

Gif-1230. Largeau, S Sahara, Tchad, K-339

Valvata shells at base of thin calcareous diatomic layer, on landing field at Largeau ( $17^{\circ} 56^{\prime} \mathrm{N}$ Lat, $18^{\circ} 07^{\prime} \mathrm{E}$ Long).

Gif-1234. Kichi-Kichi, Tchad, K-289

$3380 \pm 130$

Valvata shells at base of calcareous silt with diatoms, $48 \mathrm{~km} \mathrm{~S} \mathrm{E} \mathrm{of}$ well of Kichi-Kichi (17 $17^{\prime} \mathrm{N}$ Lat, $17^{\circ} 47^{\prime} \mathrm{E}$ Long). Comment: agrees well with stratigraphy.

Gif-1229. Well of Kelba, Tchad, S-1639

$3500 \pm 150$

Organic remains in sand, $4.75 \mathrm{~m}$ depth, in well of Kelba $\left(13^{\circ} 45^{\prime}\right.$ $\mathrm{N}$ Lat, $16^{\circ} 31^{\prime} \mathrm{E}$ Long). Comment: inserted in lacustrine series of Labdé (Sequence $\mathrm{l}_{2}$ ); to be related to a regressive phase.

\section{Gif-1264. Angamma, Tchad, K-32}

Nodule of calcareous sandstone, atop a deltaic body at Angamma, $32 \mathrm{~km} \mathrm{E}$ of Kichi-Kichi, Tibesti (17 $34^{\prime} \mathrm{N}$ Lat, $17^{\circ} 38^{\prime}$ E Long). Comment: 2 dates for base of this body: $9260 \pm 140$ (T-731) and 10,160 160 (T-732) (Servant et al., 1969) show that deltaic series is entirely Holocene, when rivers were flowing and this area was in a pluvial zone. 
Gif-1231. Largeau, Tchad, K-354

$7000 \pm 170$ in outcrop $5 \mathrm{~km}$ ENE E Long).

\section{Gif-1227. Well of Tjéri, Tchad, S-1608}

$8750 \pm 200$ Tjéri $\left(13^{\circ} 4^{\prime} \mathrm{N}\right.$ trine cycle of Labdé series.

\section{Gif-1226. Well of Tjéri, Tchad, S-1604}

$9000 \pm 200$

Organic remains in clayey layer with diatoms, depth $7.75 \mathrm{~m}$, in well of Tjéri. Comment: same layer as Gif-1227, slightly deeper.

\section{Gif-1095. Koro-Toro, Tchad, S-1165}

$9470 \pm 220$

Melania shell in outcrop of marly layer above sand, at top of cliff, NNE Koro-Toro $\left(16^{\circ} 05^{\prime}\right.$ N Lat, $18^{\circ} 29^{\prime}$ E Long), Bahr-el-Ghazal, Tchad. Comment: base of diatomaceous Sequence $1_{2}$.

\section{Gif-801. Kamala, Tehad, S-826}

$10,100 \pm 230$

$10.50 \mathrm{~m}$. $10.50 \mathrm{~m}$ thick, in wall of a well, Kamala $\left(13^{\circ} 02^{\prime} \mathrm{N}\right.$ Lat, $16^{\circ} 15^{\prime} \mathrm{E}$ Long). Comment: dates transgression of ancient lake and belongs to lower part of Sequence $l_{2}$.

Gif-1094. Nedeley, Tchad, S-1116

$10,100 \pm 230$

Vegetal debris in silt under remains of Holocene diatomites in outcrop, $2 \mathrm{~km} \mathrm{~S}$ of well at Nedeley $\left(15^{\circ} 35^{\prime} \mathrm{N}\right.$ Lat, $18^{\circ} 10^{\prime} \mathrm{E}$ Long), Bahrel-Ghazal, Tchad. Comment: base of diatomaceous Sequence $1_{2}$.

\section{Gif-1097. Nedeley, Tchad, S-1121}

$10,900 \pm 300$

Clayey limestone with diatoms and impressions of reeds on $\mathrm{E}$ flank of Bahr-el-Ghazal valley, Nedeley (15 $35^{\circ} \mathrm{N}$ Lat, $18^{\circ} 08^{\prime} \mathrm{E}$ Long), Tchad. Coll. and subm. 1967 by M. Servant. Comment: end of the lst Sequence $\mathrm{l}_{2}$ of lacustrine Labdé series.

\section{Gif-1233. Kichi-kichi, Tchad, K-294}

$11,950 \pm 280$

Lacustrine shells in sand intercalated between lacustrine sediment with gravel, $48 \mathrm{~km}$ SE of Kichi-Kichi well $\left(17^{\circ} 19^{\prime} \mathrm{N} \mathrm{Lat,} 17^{\circ} 47^{\prime} \mathrm{E}\right.$ Long). Comment: belongs in Sequence $1_{2}$.

Gif-847. Djazena, Tchad, S-1055

$12,060 \pm 380$

Biomphalaria and Bulinus shells in marly layer at base of lacustrine 
sequence, $8.85 \mathrm{~m}$ depth in well at Djazena $\left(13^{\circ} 48^{\prime} \mathrm{N}\right.$ Lat, $17^{\circ} 36^{\prime} \mathrm{E}$ Long), Tchad. Comment: dates end of Sequence $1_{2}$.

Gif-1228. Well of Kelba, Tchad, S-1633

$21,900 \pm 700$

19,950 в.c.

Sandy, silty limestone with ostracods between 2 eolian-sand deposits, depth $12.30 \mathrm{~m}$ in Kelba well. Comment: dates lacustrine unit in Soulias series.

Gif-800. Well of Kamala, Tchad, S-819 $\geqslant 35,000$

Fine limestone from thin calcareous layer in lacustrine sequence between 2 periods of sand reworking; $15.35 \mathrm{~m}$ in well of Kamala. Comment: upper part of lacustrine unit of Soulias series.

General Comment: 2 lacustrine transgressions were dated in Labdé series; the last one, which corresponds to Sequence $l_{2}$, is the longest, characterized by 2 regressive episodes ca. 8500 to 7000 B.P. and 4000 to 3500 B.P. During the 2 last millennia, the lowest regions of Tchad, $\mathbf{N}$ of the 16th parallel, connected with Lake Tchad, until 150 B.P.

\section{Gif-1028. Chari River, S Lake Tchad, Ref. $23 \quad 6270$ в.c. \\ $8220 \pm 190$
6270 B.C.}

Varved silt with vegetal debris, $3 \mathrm{~m}$ depth, from left bank of Chari, $65 \mathrm{~km}$ SSE Fort-Lamy, S Lake Tchad (11 $34^{\prime} \mathrm{N}$ Lat, $15^{\circ} 17^{\prime} \mathrm{E}$ Long). Coll. 1965 and subm. 1967 by B. Dupont, O.R.S.T.O.M., Fort Lamy, Tchad. Comment: dates a lacustrine period.

Gif-1029. Lake Tchad, Ref. 663

A.D. 1490

$460 \pm 95$

Hardened silt with organic remains, 40 to $50 \mathrm{~cm}$ depth in sediments, between lacustrine layers, $2.90 \mathrm{~m}$ below surface of Lake Tchad $\left(13^{\circ} 27^{\prime}\right.$ N Lat, 14 $30^{\prime}$ E Long). Coll. and subm. 1967 by B. Dupont. Comment: marks regression of lake; helps to calculate sedimentation rate of $1 \mathrm{~m} / \mathrm{yr}$ (Dupont and Delibrias, 1970).

\section{Sebkha de N'Dramcha series, Mauritania}

Shells from coastal Sebkha de N'Dramcha, N of Nouakchott, Mauritania. Stratigraphy of upper Quaternary in region shows 2 marine transgressions separated by a dry period with dune accumulation; last marine episode was followed by evaporation, indicated by a silty-gypsiferous layer. Coll. and subm. 1967 by C. Fontes, Fac. Sci., Paris.

\section{Gif-852. Sebkha de N'Dramcha, N. K-171}

$6000 \pm 160$

Cardium edule, ca. $2 \mathrm{~m}$ depth in silty-gypsiferous layer $\left(18^{\circ} 36^{\prime} \mathrm{N}\right.$ Lat, $15^{\circ} 46^{\prime} \mathrm{W}$ Long). Comment: dates beginning of evaporation series, following closing of gulf.

Gif-853. Sebkha de N'Dramcha, N. K-172

$6370 \pm 160$

Shells (Venus sp.) of various forms, $90 \mathrm{~cm}$ below N.K-171, in quartzose sediment, partly terrigenous $\left(18^{\circ} 36^{\prime} \mathrm{N}\right.$ Lat, $15^{\circ} 46^{\prime} \mathrm{W}$ Long). Comment: dates maximum of Nouakchottian transgression. 
Gif-856. Sebkha de N'Dramcha, N. K-193

$\mathrm{W}$ Lat ). Comment: occupies a central position related to supposed outlines of Nouakchottian gulf; expected to be much older.

Gif-854. Sebka de N'Dramcha, N. K-191

Arca senilis from lumachelle cropping out from recent formation, NW of Sebkha $\left(18^{\circ} 55^{\prime} \mathrm{N}\right.$ Lat, $15^{\circ} 23^{\prime} \mathrm{W}$ Long). Comment: belongs to shell-rich shore of Upper Inchirian.

Gif-855. Sebkha de N'Dramcha, N. K-192

Arca senilis, $30 \mathrm{~cm}$ below surface (18 $52^{\prime} \mathrm{N}$ Lat, $15^{\circ} 28^{\prime} \mathrm{W}$ Long). General Comment: dates determine shorelines corresponding to Nouakchottian and Inchirian extensions of gulf.

\section{Delta of Ogooué series, Gabon}

Algae and mollusk shells from calcareous submarine layer, off delta of Ogooué, on continental shelf of Gabon. Coll. by dredging and subm. 1965 by P. Giresse, Fac. Sci., Caen.

Gif-456. Delta of Ogooué, G-600-50

50 to $60 \mathrm{~cm}$ depth $\left(0^{\circ} 23^{\prime} \mathrm{S}\right.$ Lat, $8^{\circ} 55^{\prime} \mathrm{E}$ Long).

Gif-457. Delta of Ogooué, G-300-15

10 to $20 \mathrm{~m}$ depth $\left(0^{\circ} 31^{\prime} \mathrm{S}\right.$ Lat, $8^{\circ} 56^{\prime} \mathrm{E}$ Long $)$.

General Comment: expected to date an ancient shoreline; but obviously dredged material was not in situ.

\section{Gif-871. Terrace of Benoué, N Cameroun}

Fossil soil from middle terrace of Benoué R., $10 \mathrm{~m}$ above floodplain, near confluence of Benoué and Mayr Kebi Rivers $\left(9^{\circ} 15^{\prime} \mathrm{N}\right.$ Lat, $13^{\circ}$ 22' E Long). Coll. and subm. 1967 by G. Sifferman, Lab. de Géol. et Paléontol., Strasbourg. Comment: corresponds to moist period already dated in Tchad.

\section{Brazil coast series}

\section{South America}

Series of shells, along Brazilian littoral, from fossil lines of Vermetidae and uplifted reefs, near Recife and Ila Grande, $2000 \mathrm{~km}$ apart. Part of study of variations of sea level in the Holocene. Coll. and subm. 1967 by J. Laborel, Fac. Sci., Abidjan.

Gif-1059. Sitio Forte, Ila Grande, J.L. Br-67-1

Vermets limestone $\left(23^{\circ} \mathrm{S}\right.$ Lat, $45^{\circ} \mathrm{W}$ Long $),+2.60 \mathrm{~m}$.

\section{Gif-1060. Sitio Forte, Ila Grande,}

$$
\text { J.L. Br-67-2 }
$$

$$
3420 \pm 110
$$$$
1470 \text { в.c. }
$$

$$
1670 \pm 100
$$

A.D. 280

Vermets and Balanes limestone (23 $\mathrm{S}$ Lat, $45^{\circ} \mathrm{W}$ Long), $+1.70 \mathrm{~m}$. 
Gif-1061. Sitio Forte, Ila Grande,

\section{J.L. Br-67-3}

A.D. 1570

Vermets limestone $\left(23^{\circ} \mathrm{S}\right.$ Lat, $45^{\circ} \mathrm{W}$ Long), ca. $+0.50 \mathrm{~m}$.

Gif-1062. Reef of Rio Doce, Olinda,

$3100 \pm 120$

Pernambuco, J.L. Br-67-4

1150 B.c. $+3 \mathrm{~m}$.

Madreporaire (Montastrea cavernosa) ( $8^{\circ} \mathrm{S}$ Lat, $37^{\circ} 10^{\prime} \mathrm{W}$ Long),

Gif-1066. Reef of Rio Doce, Olinda, Pernambuco, J.L. Br-67-8

$1830 \pm 110$

A.D. 120

Madreporaire (Siderastrea stellata), ( $8^{\circ} \mathrm{S}$ Lat, $37^{\circ} 10^{\prime} \mathrm{W}$ Long), ca. present sea level.

Gif-1063. Reef of Rio Doce, Olinda, Pernambuco, J.L. Br-67-5

A.D. 1560

$390 \pm 90$

Melobesiees limestone ( $8^{\circ} \mathrm{S}$ Lat, $37^{\circ} 10^{\prime} \mathrm{W}$ Long), ca. $+50 \mathrm{~cm}$.

Gif-1064. Lagoa de Itahype, Ilheus, Bahia, J.L. Br-67-6

$4070 \pm 140$

2120 B.C.

Madreporaire (Mussismilia braziliensis), (14 $14^{\circ} 30^{\prime} \mathrm{S}$ Lat, $39^{\circ} \mathrm{W}$ Long), ca. present sea level. Comment: species not now living in region.

Gif-1065. Ilha de Caieira, Vitoria Bay,

$5520 \pm 150$ Espiritu Santo, J.L. Br-67-7

3570 B.C.

Mussismilia harttii (20 $10^{\circ} \mathrm{S}$ Lat, $40^{\circ} 15^{\prime} \mathrm{W}$ Long). Comment: species not now living in this lat.

General Comment: good correlation between dates and levels for these coastal regions of Brazil, $2000 \mathrm{~km}$ apart. Confirms existence in Brazil of recent variations of sea level as indicated by Van Andel and Laborel (1964) and studied by Bigarella (1965). Gif-1064 and -1065 date a climatic optimum because of disappearance of species from region.

\section{Sambaqui da Pedra Oca series, Brazil}

Shells from Sambaqui da Pedra Oca, Bahia de Todos (12 $51^{\prime} \mathrm{S}$ Lat, $38^{\circ} 31^{\prime}$ W Long), Santos, Brazil (Calderon, 1964). Coll. and subm. 1969 by J. Labeyrie.

\section{Gif-877. Sambaqui da Pedra Oca 1}

$2180 \pm 110$

Taken from beach rock under sambaqui, ca. $+1 \mathrm{~m}$ of present sea level.

Gif-878. Sambaqui da Pedra Oca 2

Shell from basal horizon of sambaqui, above beach rock.

General Comment: dates construction of Sambaqui, just after a slight marine transgression. 
Rio de la Plata series, Argentina

Marine shells in Rio de la Plata, Argentina, a few $\mathrm{km}$ off present littoral, giving ancient position of littoral (Ottman and Urien, 1966). Subm. 1966 by F. Ottman.

\section{Gif-736. Rio de la Plata 1}

Shells dredged from black silt under sediment, S Arquimedes bank, $\left(35^{\circ} 12^{\prime} \mathrm{N}\right.$ Lat, $56^{\circ} 17^{\prime} \mathrm{W}$ Long) in lagoon formation, attributed to a slightly regressive episode.

\section{Gif-737. Rio de la Plata 2}

Shells from beach ridge farthest inland, a few $\mathrm{m}$ above present sea level, Rio de la Plata.

General Comment: no precise indication of alt of samples but in this very flat country, slight variation of sea level can explain penetration of sea a few km inland; Gif-737 may date maximum of a transgression.

\section{Miscellaneous Countries}

\section{Gif-835. Neutraubling, Bavaria}

$13,500 \pm 300$

Bone, $1.60 \mathrm{~m}$ depth in layer of Danube alluvium, $10 \mathrm{~m}$ thick, Neutraubling, SE of Regensburg (48 $58^{\circ} \mathrm{N}$ Lat, $12^{\circ} 11^{\prime} \mathrm{E}$ Long), Bavaria. Coll. 1962 and subm. 1967 by M. Léger, Inst. de Géog., Paris. Comment: date shows upper part of layer belongs to older Dryas and not to end of Würm, as supposed (Léger, 1965). Collagen not extracted for measurement.

\section{Gif-780. Aalter, Belgium}

$2810 \pm 150$

$\mathrm{B}_{2} \mathrm{~h}$ horizon of Podzol beneath eolian sand $75 \mathrm{~cm}$ thick, Aalter, 20 $\mathrm{km} \mathrm{NW}$ Gand $\left(50^{\circ} 50^{\prime} \mathrm{N}\right.$ Lat, $3^{\circ} 29^{\prime}$ E Long), Belgium. Coll. and subm. 1966 by C. Sys, Ruks Univ., Ghent. Comment: Roman ceramics overlie the Podzol.

\section{Gif-781. Anzegem, Belgium}

$2410 \pm 150$

$\mathrm{B}_{2} \mathrm{~h}$ horizon beneath eolian sands $70 \mathrm{~cm}$ thick, Anzegem, $30 \mathrm{~km} \mathrm{SW}$ Ghent ( $51^{\circ} 07^{\prime} \mathrm{N}$ Lat, $3^{\circ} 28^{\prime} \mathrm{E}$ Long), Belgium. Coll. and subm. 1966 by C. Sys. Comment: like Gif-780, dates overlying sand of sandy region of Flanders.

\section{Gif-897. Xivares, Asturias, Spain}

Shells (Purpura hoemastoma), from Xivares beach $\left(43^{\circ} 34^{\prime} \mathrm{N}\right.$ Lat, $2^{\circ} 02^{\prime}$ W Long), Cabo Penas, Asturias, Spain. Alt $+3 \mathrm{~m}$. Coll. and subm. 1967 by G. Mary, Fac. Sci., Univ. Caen. Comment: in this region recent crustal movement is not excluded. 


\section{Gif-730. S W Madeira Island}

$14,900 \pm 450$

12,950 в.C.

Mollusk shells and calcareous algae from shell rocks, $1900 \mathrm{~m}$ depth, $15 \mathrm{~km}$ off Funchal, SW Madeira (32 $33^{\prime} \mathrm{N}$ Lat, $16^{\circ} 56^{\prime} \mathrm{W}$ Long). Coll. 1966 with bucket of Bathyscaphe by C. Pareyn; subm. 1967 by C. Pareyn and L. Dangeard. Comment: considered to be of littoral origin. Possibility of rapid subsidence in this volcanic region is not excluded.

\section{Ile Maré series, New Caledonia}

Ile Maré, one of Iles Loyauté, is coral atoll $\left(21^{\circ} 30^{\prime} \mathrm{S}\right.$ Lat, $168^{\circ} \mathrm{E}$ Long). Coral samples coll. at surface, and subm. 1967 by J. P. Chevalier, Inst. de Paléontol., Paris.

Gif-1024. Maré, M.A.-64

From reef knoll in lagoon. Comment: date is infinite, as expected.

Gif-1025. Maré, M.A.-83

$\geqslant \mathbf{3 0 , 0 0 0}$

From side of La Rocheknoll, on the ring. Comment: age expected: Pleistocene.

Gif-1026. Maré, M.A.-133

From Terrace 13, alt $+4 \mathrm{~m}$ related to highest sea level. Comment: Holocene expected.

Gif-1027. Maré, M.A.-172

From Terrace 14, alt $+2 \mathrm{~m}$ related to highest sea level. Comment: Holocene expected.

General Comment: Maré atoll seems to be recently uplifted ancient atoll, because most dated Pacific atolls have surface ages of 3000 to $5000 \mathrm{yr}$.

\section{Gif-892. Motu Manu, Atoll de Mapelia, $\quad 3450 \pm 130$ French Polynesia, No. $505 \quad 1500$ B.c.}

Calcareous coral, at Motu Manu, Atoll de Mapelia (16 $47^{\prime} \mathrm{S}$ Lat, $153^{\circ} 59^{\prime} \mathrm{W}$ Long), alt $+1 \mathrm{~m}$. Coll. and subm. 1967 by A. Guilcher. Comment: confirms existence of higher recent sea level, in Pacific, as shown at Mururoa atoll by the authors (R., 1969, v. 11, p. 337-338) and by Thurber et al. (1965).

\section{Gif-893. Motu Mote, Bora-Bora, French Polynesia, No. 581$$
2250 \pm 130
$$$$
300 \text { B.c. }
$$

Calcareous coral from E passage Motu Mote, Barrier of Bora-Bora, French Polynesia ( $16^{\circ} 27^{\prime} \mathrm{S}$ Lat, $151^{\circ} 45^{\prime} \mathrm{W}$ Long). Coll. and subm. 1967 by A. Guilcher. Comment: same as for Gif-892.

\section{Gif-823. Tapao, Phum Chhuk, Wompong Cham, Cambodia}

Peaty sample from core at $80 \mathrm{~m}$ depth, in alluvium of Mekong, at Tapao, Phum Chhuk (12 $09^{\prime} \mathrm{N}$ Lat, $105^{\circ} 44^{\prime} \mathrm{E}$ Long), Kompong Cham, Cambodia. Coll. and subm. by J. P. Carbonnel, C.N.R.S., Paris. Com- 
ment: corresponds to ancient phase filling of Mekong valley; too old to be precisely placed in history of aggradation.

\section{Mannavanur series, Madras, Madurai dist., India}

Peaty sediments from marsh in a swale at Mannavanur $\left(10^{\circ} 13^{\prime} \mathrm{N}\right.$ Lat, $77^{\circ} 20^{\prime} \mathrm{W}$ Long), alt $2100 \mathrm{~m}$, Madras State, Madurai dist., India. Coll. and subm. 1967 by F. Blasco, Inst. Fr., Pondichery, India.

Gif-1136. Mannavanur, I.F.P. . $_{1}$ $780 \pm 90$ 40 to $50 \mathrm{~cm}$ depth, black silty mud with $30 \%$ organic matter.

\section{Gif-1137. Mannavanur, I.F.P..$_{3}$}

$900 \pm 100$

$110 \mathrm{~cm}$ depth, sand with $2.8 \%$ organic matter.

General Comment: recent increase of sedimentation in this depression due to erosion related to destruction of vegetation by man. Rapid sedimentation rate explains why there is no change in pollen composition throughout the profile.

\section{Gif-775. Christmas Harbour, Kerguelen 0-58}

A.D. 1770

$780 \pm 100$

Organic remains, $1.20 \mathrm{~m}$ depth, in "peatbog", on a hillside, Bay of Christmas ( $48^{\circ} 40^{\prime} \mathrm{S}$ Lat, $69^{\circ} 10^{\prime} \mathrm{E}$ Long), Kerguelen. Bog, $1.50 \mathrm{~m}$ thick, lies on gravel bed. Coll. 1965 and subm. 1966 by N. Bellair, Fac. Sci., Paris. "Peatbog" on this island designates thick spongy soil containing abundant organic remains. Comment: pollen analysis indicates 2 cold periods: one at base of peat bog, and a 2nd one from 40 to $80 \mathrm{~cm}$ depth (Bellair and Delibrias, 1967).

\section{GROUND WATER SAMPLES}

No systematic program for dating ground waters of aquifers exists at the laboratory. Nevertheless, we undertook a short study of aquifers of Saudi Arabia and some preliminary measurements for aquifers of the Paris Basin, now being studied by other laboratories. In Saudi Arabia, water was sampled from aquifers of Wasi-Biyadh and of Minjur and from their respective outcrops; subm. 1967-1968 by Soc. Grenobloise d'Etudes et d'Applications Hydrauliques (SOGREAH) to determine if these aquifers are currently being supplied. Some dates were already obtained by Thatcher et al. (1961).

For aquifers of the Paris Basin, samples were subm. by Vuillaume, B.R.G.M., Orléans. Measurements are reported as \% of modern, without correction for limestone dilution.

\section{Wasia-Biyadh Aquifer, Saudi Arabia}

\section{Gif-905. Wadi Nisah, S-9}

$150 \mathrm{~m}$ below water table, middle Wadi Nisah $\left(24^{\circ} 10^{\prime} \mathrm{N}\right.$ Lat, $46^{\circ}$ 42' E Long). 
Gif-906. Bijidiyan-Khardj, S-426

(24 $14^{\prime}$ N Lat, $47^{\circ} 33^{\prime}$ E Long).

Gif-908. Khurais, K.S.W.W.J.

$11.3 \pm 0.6$

$50 \mathrm{~m}$ depth from top of the aquifer, at Khurais $\left(25^{\circ} 03^{\prime} \mathrm{N}\right.$ Lat, $47^{\circ}$ $56^{\prime}$ E Long).

Gif-907. Layla, S-892

$\left(22^{\circ} 21^{\prime} \mathrm{N}\right.$ Lat, $46^{\circ} 49^{\prime}$ E Long).

Minjur Aquifer, Saudi Arabia

Gif-910. $M_{1}$, Minjur outcrop, S-1524

$16.5 \pm 0.7$ Long).

Middle part of lower Minjur formation $\left(24^{\circ} 30^{\prime} \mathrm{N}\right.$ Lat, $45^{\circ} 48^{\prime} \mathrm{E}$

Gif-909. Shaqra, S-1090

Upper part of the lower Minjur formation $\left(25^{\circ} 15^{\prime} \mathrm{N}\right.$ Lat, $45^{\circ} 15^{\prime}$ E Long).

\section{Gif-901. Hayr, S-7}

$4.7 \pm 0.6$

$46 \mathrm{~m}$ below water table, upper part of upper Minjur formation $\left(24^{\circ}\right.$ $26^{\prime} \mathrm{N}$ Lat, $46^{\circ} 47^{\prime}$ E Long).

Gif-912. Majma'ah, S.999

$4.0 \pm 0.6$

$168 \mathrm{~m}$ below water table, middle part of upper Minjur formation (25 $53^{\prime} \mathrm{N}$ Lat, $45^{\circ} 21^{\prime}$ E Long).

Gif-913. W. Bu'ayja, S-8

$$
1.75 \pm 0.4
$$

(24 $19^{\prime} \mathrm{N}$ Lat, $46^{\circ} 50^{\prime} \mathrm{E}$ Long).

Gif-902. Jiza, S-105

$117 \mathrm{~m}$ below water table, middle part of upper Minjur formation (24 $34^{\prime}$ N Lat, $46^{\circ} 45^{\prime}$ E Long).

Gif-900. Riyadh Shumeyssi, S-46

$197 \mathrm{~m}$ below water table, lower part of the upper Minjur formation (24 $39^{\prime} \mathrm{N}$ Lat, $46^{\circ} 43^{\prime} \mathrm{E}$ Long).

Gif-904. Dirab, S-431

$103 \mathrm{~m}$ below water table, middle part of upper Minjur formation (24 $25^{\prime} \mathrm{N}$ Lat, $46^{\circ} 30^{\prime} \mathrm{E}$ Long).

Gif-914. Drumah, S-429

(24 $38^{\prime} \mathrm{N}$ Lat, $46^{\circ} 09^{\prime} \mathrm{E}$ Long).

General Comment: measurements, accompanied by a classic hydrodynamic study, lead to conclusion that recharge for both aquifers is now 
very inferior to discharge; hence, these formations are being depleted naturally, without exploitation.

\section{Albian Aquifer of Paris Basin, France}

Gif-600. Radio House, Paris

Well (48 $52^{\prime} \mathrm{N}$ Lat, $2^{\circ} 20^{\prime} \mathrm{E}$ Long).

Gif-604. Issy-les-Moulineaux, Seine

Well (48 $49^{\prime} \mathrm{N} \mathrm{Lat,} 2^{\circ} 17^{\prime}$ E Long).

Gif-605. Fleury-la-Vallée, Yonne, FvH

Outcrop ( $47^{\circ} 53^{\prime}$ N Lat, $3^{\circ} 26^{\prime}$ E Long).

Gif-606. Chichery-la-Ville, Yonne, ch.v.J

Outcrop (47 $55^{\prime}$ N Lat, $3^{\circ} 31^{\prime}$ E Long).

Gif-607. Viry-Châtillon, Essonne, V.c.A

Artesian well $\left(48^{\circ} 40^{\prime} \mathrm{N}\right.$ Lat, $2^{\circ} 23^{\prime} \mathrm{E}$ Long).

Gif-601. Dige, Yonne, $\mathbf{K}_{1}-\mathbf{K}$

$100 \pm 1.05$

Outcrop ( $47^{\circ} 43^{\prime} \mathrm{N}$ Lat, $3^{\circ} 22^{\prime}$ E Long).

Gif-602. Dracy, Yonne, $\left(\mathbf{A}_{1}-\mathbf{A}_{4}\right)$

$49.5 \pm 0.8$

Outcrop (47 $46^{\prime} \mathrm{N}$ Lat, $3^{\circ} 16^{\prime} \mathrm{E}$ Long).

Gif-603. Mantes, Yvelines

Well (485' $59^{\prime}$ Lat, $1^{\circ} 43^{\prime}$ E Long).

$6.2 \pm 0.6$

IV. ATMOSPHERIC SAMPLES

All atmospheric $\mathrm{CO}_{2}$ samples coll. to determine increase of $\mathrm{C}^{14} / \mathrm{C}^{12}$ ratio due to explosion of nuclear devices, and measured between publication of our first results (R., 1964, v. 6, p. 248-249) and end of 1970, reported here.

Technique for $\mathrm{CO}_{2}$ collection is the same as used previously, i.e., by bubbling air through solutions of $\mathrm{NaOH}$. Flow-rate is chosen to obtain a quasi-total collection of $\mathrm{CO}_{2}$.

Recently, $\delta \mathrm{C}^{13}$ measurements have become available for filling gases; corrections are now applied to $\delta \mathrm{C}^{14}$, taking these values in consideration. For all other measurements, value of $-11 \%$ corresponding to average of measured $\delta \mathrm{C}^{13}$, was assumed.

\section{Val Joyeux series, France}

Scientific sta., Val Joyeux, Univ. of Paris, $10 \mathrm{~km}$ from Versailles, in the countryside, until now situated away from large roads $\left(48^{\circ} 49^{\prime} \mathrm{N}\right.$ Lat, $2^{\circ} 01^{\prime} \mathrm{E}$ Long). Mostly level atmosphere comes from $\mathrm{W}$ and, therefore, is not contaminated with $\mathrm{CO}_{2}$ coming from industrial area of Paris which extends $20 \mathrm{~km}$ to $70 \mathrm{~km} \mathrm{E}$ of Val Joyeux. All coll. samples are reported here. In Fig. 1, $\Delta \mathrm{C}^{14}$ for samples coll. before 1963 (R., 1964, v. 6 , p. 248-249) have been recalculated with $\delta \mathrm{C}^{13}$ value equal to $-11 \%$. 


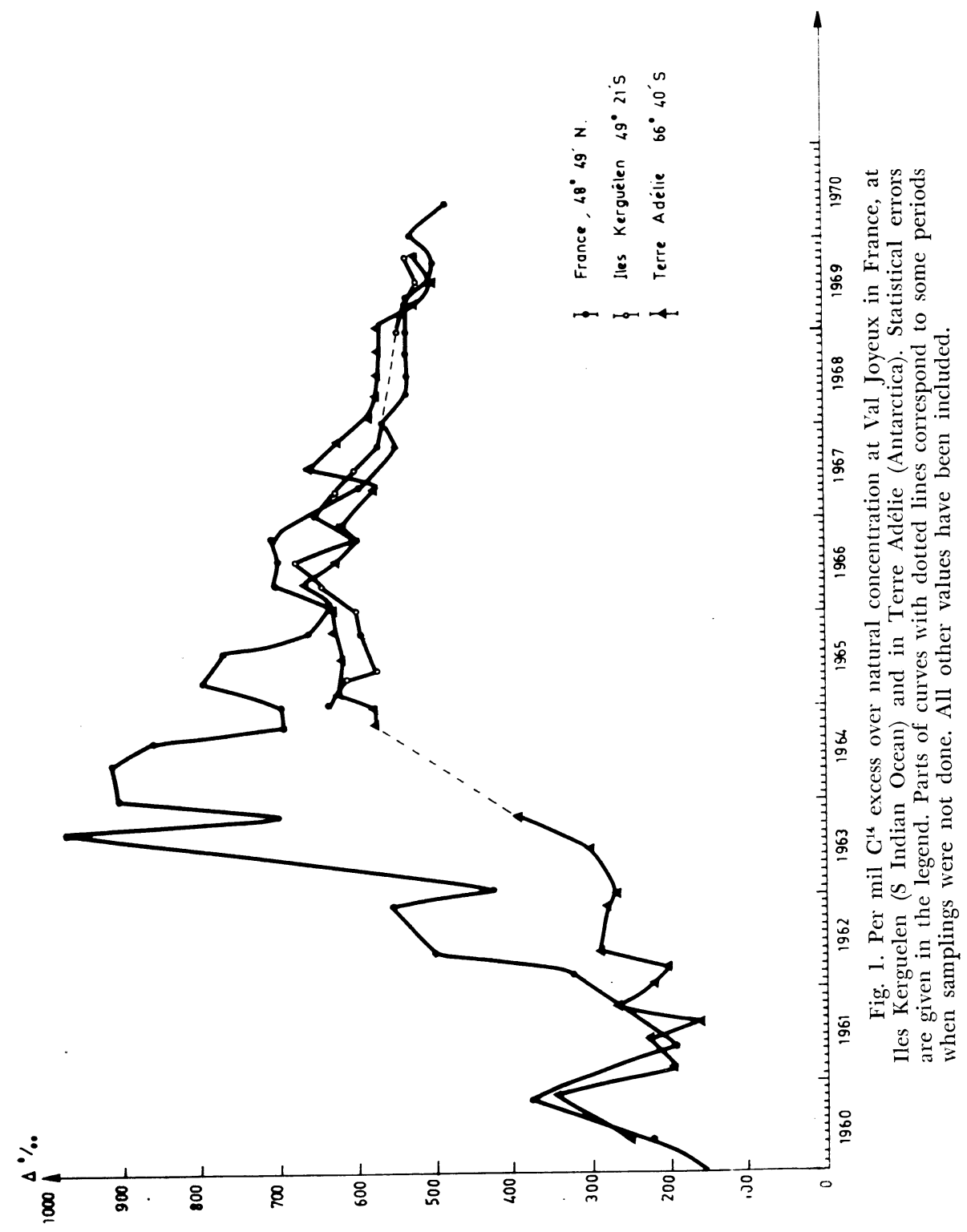




\begin{tabular}{|c|c|c|c|c|c|c|}
\hline Date no. & Sample no. & Month Day & Year & $\delta \mathrm{C}^{14} \%$ & $\delta \mathrm{C}^{13} \%$ & $\Delta \% o$ \\
\hline Gif-2000 & 63-I-A & Jan. 14-31 & 1963 & 465 & $(-11) *$ & $424 \pm 14$ \\
\hline Gif-2001 & 63-III-A & Aug. $\quad 1-9$ & 1963 & 1030 & $(-11)$ & $973 \pm 15$ \\
\hline Gif-2002 & 63-IV-A & Oct. $17-24$ & 1963 & 750 & $(-11)$ & $701 \pm 14$ \\
\hline Gif-2003 & 64-I-A & $\begin{array}{ll}\text { Jan. } & 24-31 \\
\text { Apr. } & 28 \text { to }\end{array}$ & 1964 & 960 & $(-11)$ & $905 \pm 14$ \\
\hline Gif-2004 & 64-II-A & May 6 & 1964 & 970 & $(-11)$ & $915 \pm 14$ \\
\hline Gif-2005 & 64-III-A & Aug. 13-25 & 1964 & 910 & $(-11)$ & $857 \pm 15$ \\
\hline \multirow[t]{2}{*}{ Gif-2006 } & 64-IV-A & Oct. 28 to & & & & \\
\hline & & Nov. 7 & 1964 & 740 & $(-11)$ & $691 \pm 13$ \\
\hline Gif-2007 & 65-I-A & Jan. 12-31 & 1965 & 750 & $(-11)$ & $701 \pm 13$ \\
\hline Gif-2008 & 65-II-A & Apr. 14-22 & 1965 & 850 & $(-11)$ & $798 \pm 14$ \\
\hline Gif-2009 & 65-III-A & July $\quad 1-7$ & 1965 & 820 & $(-11)$ & $769 \pm 14$ \\
\hline Gif-2010 & 65-IV-A & Nov. $10-20$ & 1965 & 710 & $(-11)$ & $662 \pm 13$ \\
\hline Gif-2011 & 66-I-A & Feb. $\quad 1-21$ & 1966 & 680 & $(-11)$ & $633 \pm 13$ \\
\hline Gif-2012 & 66-II-A & Apr. $18-25$ & 1966 & 760 & $(-11)$ & $711 \pm 13$ \\
\hline Gif-2013 & 66-III-A & July $\quad 1-8$ & 1966 & 750 & $(-11)$ & $701 \pm 13$ \\
\hline Gif-2014 & 66-IV-A & Oct. $11-17$ & 1966 & 760 & $(-11)$ & $711 \pm 13$ \\
\hline Gif-2015 & $67-\mathrm{I}-\mathrm{A}$ & Jan. 10-18 & 1967 & 705 & $(-11)$ & $658 \pm 13$ \\
\hline Gif-2016 & 67-II-A & Apr. $10-14$ & 1967 & 660 & $(-11)$ & $614 \pm 13$ \\
\hline \multirow[t]{2}{*}{ Gif-2017 } & 67-III-A & July 27 to & & & & \\
\hline & & Aug. 7 & 1967 & 640 & $(-11)$ & $594 \pm 13$ \\
\hline Gif-2018 & 67-IV-A & Oct. $19-25$ & 1967 & 590 & $(-11)$ & $546 \pm 12$ \\
\hline Gif-2019 & 68-I-A & Jan. 12-17 & 1968 & 609 & $(-11)$ & $564 \pm 12$ \\
\hline Gif-2020 & 68-II-A & Apr. $\quad 4-10$ & 1968 & 577 & $(-11)$ & $533 \pm 13$ \\
\hline Gif-2021 & 68-III-A & July $\quad 3-9$ & 1968 & 580 & $(-11)$ & $536 \pm 13$ \\
\hline Gif-2022 & 68-IV-A & Oct. $15-21$ & 1968 & 580 & $(-11)$ & $536 \pm 13$ \\
\hline Gif-2023 & 69-I-A & Jan. 24-31 & 1969 & 580 & $(-11)$ & $536 \pm 13$ \\
\hline Gif-2024 & 69-II-A & Apr. $25-30$ & 1969 & 580 & $(-11)$ & $536 \pm 13$ \\
\hline Gif-2025 & 69-III-A & July 10-16 & 1969 & 561 & -9.6 & $513 \pm 13$ \\
\hline Gif-2026 & 69-IV-A & Oct. $22-28$ & 1969 & 540 & $(-11)$ & $497 \pm 13$ \\
\hline Gif-2027 & 70-I-A & Jan. 15-26 & 1970 & 577 & -10.2 & $530 \pm 13$ \\
\hline Gif-2028 & 70-II-A & Apr. $\quad 3-8$ & 1970 & 515 & -13.2 & $479 \pm 13$ \\
\hline Gif-2029 & 70-III-A & July & 1970 & 556 & -10.24 & $515 \pm 13$ \\
\hline
\end{tabular}

* $\delta \mathrm{C}^{13}$ assumed

General Comment: variations are similar to those already pub. by many laboratories: rapid increase of $\Delta \mathrm{C}^{14}$ in 1963, followed by a progressive decrease pulsed by a yearly injection ("Spring injection") which grows less important and disappears completely after 1966.

\section{Iles Kerguelen series}

Atmospheric $\mathrm{CO}_{2}$ coll. at scientific sta. Port aux Français, Iles Kerguelen (49 $21^{\prime} \mathrm{N}$ Lat, $70^{\circ} 13^{\prime} \mathrm{E}$ Long) begun in 1965 by technicians of Terres Australes and Antarctiques Françaises. Small building shelter- 
ing sampling apparatus, away from main sta., was accidentally destroyed in 1968, leaving no samples for April, July, and October 1968. Every year, in January, bottles with $\mathrm{NaOH}$ solution are brought back from Kerguelen to Gif with equipment of expedition.

\begin{tabular}{lllllclc}
\hline Date no. & Sample no. & Month & Day & Year & $\delta \mathrm{C}^{14 \%} \%$ & $\delta \mathrm{C}^{13 \%} \%$ & $\Delta \%$ \\
\hline Gif-2065 & K-I-65 & Jan. & $8-13$ & 1965 & 680 & $(-11)^{*}$ & $633 \pm 13$ \\
Gif-2066 & K-II-65 & Apr. & $3-7$ & 1965 & 660 & $(-11)$ & $614 \pm 13$ \\
Gif-2067 & K-III-65 & July & $5-9$ & 1965 & 620 & $(-11)$ & $575 \pm 13$ \\
Gif-2068 & K-IV-65 & Oct. & $4-9$ & 1965 & 640 & $(-11)$ & $594 \pm 13$ \\
Gif-2069 & K-I-66 & Jan. & $8-12$ & 1966 & 647 & $(-11)$ & $601 \pm 13$ \\
Gif-2070 & K-II-66 & Apr. & $2-7$ & 1966 & 697 & $(-11)$ & $647 \pm 13$ \\
Gif-2071 & K-III-66 & July & $4-8$ & 1966 & 730 & $(-11)$ & $682 \pm 14$ \\
Gif-2072 & K-IV-66 & Oct. & $5-10$ & 1966 & 640 & $(-11)$ & $594 \pm 13$ \\
Gif-2073 & K-I-67 & Jan. & $9-13$ & 1967 & 700 & -11.6 & $655 \pm 14$ \\
Gif-2074 & K-II-67 & Apr. & $8-11$ & 1967 & 674 & -10.3 & $625 \pm 13$ \\
Gif-2075 & K-III-67 & July & $1-7$ & 1967 & 643 & -12.0 & $600 \pm 13$ \\
Gif-2076 & K-IV-67 & Oct. & $2-7$ & 1967 & 608 & -12.5 & $568 \pm 13$ \\
Gif-2077 & K-I-68 & Jan. & $4-8$ & 1968 & 608 & -11.5 & $565 \pm 13$ \\
Gif-2078 & K-I-69 & Jan. & $26-30$ & 1969 & 577 & -9.2 & $543 \pm 13$ \\
Gif-2079 & K-II-69 & Apr. & $20-25$ & 1969 & 582 & -10.6 & $537 \pm 13$ \\
Gif-2080 & K-III-69 & July & $20-24$ & 1969 & 557 & -12.4 & $518 \pm 13$ \\
Gif-2081 & K-IV-69 & Oct. & $20-24$ & 1969 & 563 & -15.2 & $532 \pm 13$ \\
\hline
\end{tabular}

* $\delta \mathrm{C}^{13}$ assumed

\section{Terre Adélie, Antarctica series}

Atmospheric $\mathrm{CO}_{2}$ coll. at sta. Dumont Durville in Terre Adélie $\left(66^{\circ}\right.$ $40^{\prime} \mathrm{S}$ Lat, $140^{\circ} \mathrm{E}$ Long). Coll. made by Expeditions Polaires Françaises, Paris. Sampling began in 1960 and continued till now, except for 1964, when equipment was lost in Papeete Harbour. As in Kerguelen, samples are brought back every year.

\begin{tabular}{llllcccc}
\hline Date no. & Sample no. & Month Day & Year & $\delta \mathrm{C}^{14 \%} \%$ & $\delta \mathrm{C}^{13 \%} \%$ & $\Delta \%$ \\
\hline Gif-2030 & TA-I-60 & May $16-18$ & 1960 & 290 & $(-11)^{*}$ & $254 \pm 11$ \\
Gif-2031 & TA-II-60 & Nov. 10-15 & 1960 & 390 & $(-11)$ & $351 \pm 11$ \\
Gif-2032 & TA-I-61 & Feb. 15-17 & 1961 & 230 & $(-11)$ & $194 \pm 13$ \\
Gif-2033 & TA-II-61 & June & $1-5$ & 1961 & 260 & $(-11)$ & $225 \pm 11$ \\
Gif-2034 & TA-III-61 & Aug. 9-14 & 1961 & 190 & $(-11)$ & $157 \pm 11$ \\
Gif-2035 & TA-IV-61 & Oct. 11-15 & 1961 & 305 & $(-11)$ & $269 \pm 11$ \\
Gif-2036 & TA-I-62 & Jan. $7-9$ & 1962 & 257 & $(-11)$ & $222 \pm 11$ \\
Gif-2037 & TA-II-62 & Feb. 24 to & & & & \\
& & & Mar. 10 & 1962 & 240 & $(-11)$ & $205 \pm 11$ \\
\hline
\end{tabular}




\begin{tabular}{|c|c|c|c|c|c|c|c|}
\hline Date no. & Sample no. & Month & Day & Year & $\delta \mathrm{C}^{14} \%$ & $\delta \mathrm{C}^{13} \%$ & $\Delta \%$ \\
\hline Gif-2038 & TA-III-62 & May 1 & $12-25$ & 1962 & 325 & $(-11)$ & $288 \pm 11$ \\
\hline Gif-2039 & TA-IV-62 & Nov. & $9-24$ & 1962 & 320 & $(-11)$ & $283 \pm 11$ \\
\hline Gif-2040 & TA-V-62 & Dec. & $1-5$ & 1962 & 300 & $(-11)$ & $264 \pm 11$ \\
\hline Gif-2041 & TA-I-63 & June 1 & $12-26$ & 1963 & 340 & $(-11)$ & $302 \pm 11$ \\
\hline \multirow[t]{2}{*}{ Gif-2042 } & TA-II-63 & Sept. 2 & 24 to & & & & \\
\hline & & Oct. & 4 & 1963 & 430 & $(-11)$ & $390 \pm 12$ \\
\hline Gif-2043 & TA-III-63 & Dec. & $19-26$ & 1963 & 460 & $(-11)$ & $419 \pm 12$ \\
\hline Gif-2044 & TA-I-64 & Oct. 2 & $25-30$ & 1964 & 620 & $(-11)$ & $575 \pm 12$ \\
\hline Gif-2045 & TA-II-64 & Dec. & $2-5$ & 1964 & 620 & $(-11)$ & $575 \pm 12$ \\
\hline \multirow[t]{2}{*}{ Gif-2046 } & TA-I-65 & Feb. 2 & 26 to & & & & \\
\hline & & Mar. & 2 & 1965 & 670 & $(-11)$ & $623 \pm 12$ \\
\hline Gif-2047 & TA-II-65 & July & $1-6$ & 1965 & 660 & $(-11)$ & $615 \pm 13$ \\
\hline Gif-2048 & TA-III-65 & Oct. & $1-6$ & 1965 & 675 & $(-11)$ & $628 \pm 19$ \\
\hline Gif-2049 & TA-I-66 & Jan. & $4-10$ & 1966 & 680 & $(-11)$ & $633 \pm 13$ \\
\hline Gif-2050 & TA-II-66 & Apr. & $4-10$ & 1966 & 715 & $(-11)$ & $667 \pm 13$ \\
\hline Gif-2051 & TA-III-66 & July & $1-5$ & 1966 & 670 & $(-11)$ & $623 \pm 13$ \\
\hline Gif-2052 & TA-IV-66 & Oct. & $7-11$ & 1966 & 640 & $(-11)$ & $594 \pm 13$ \\
\hline Gif-2053 & TA-V-66 & Dec. 2 & $28-31$ & 1966 & 670 & $(-11)$ & $623 \pm 13$ \\
\hline Gif-2054 & TA-I-67 & Apr. & $1-3$ & 1967 & 620 & $(-11)$ & $575 \pm 13$ \\
\hline Gif-2055 & TA-II-67 & July & $1-5$ & 1967 & 710 & $(-11)$ & $662 \pm 14$ \\
\hline Gif-2056 & TA-III-67 & Oct. & $1-5$ & 1967 & 670 & -10.20 & $621 \pm 14$ \\
\hline Gif-2057 & TA-I-68 & Jan. & $3-5$ & 1968 & 627 & $(-11)$ & $582 \pm 13$ \\
\hline Gif-2058 & TA-II-68 & Apr. & $4-8$ & 1968 & 617 & $(-11)$ & $572 \pm 13$ \\
\hline Gif-2059 & TA-III-68 & July & $3-7$ & 1968 & 614 & -11.4 & $570 \pm 13$ \\
\hline Gif-2060 & TA-IV-68 & Oct. & $3-7$ & 1968 & 616 & $(-11)$ & $571 \pm 13$ \\
\hline Gif-2061 & TA-I-69 & Jan. & $4-8$ & 1969 & 617 & $(-11)$ & $572 \pm 13$ \\
\hline Gif-2062 & TA-II-69 & Apr. 1 & $11-15$ & 1969 & 557 & -13.6 & $522 \pm 13$ \\
\hline Gif-2063 & TA-III-69 & July & 9-13 & 1969 & 537 & -12.9 & $500 \pm 13$ \\
\hline Gif-2064 & TA-IV-69 & Oct. 1 & $10-14$ & 1969 & 561 & -12.3 & $521 \pm 13$ \\
\hline
\end{tabular}

$* \delta \mathrm{C}^{13}$ assumed

General Comment: curves of artificial $\mathrm{C}^{14}$ values vs. time obtained in Terre Adélie and in Kerguelen are not as smooth as might be expected if transfer from $\mathrm{N}$ to $\mathrm{S}$ hemispheres is the sole process. Observed variations seem to indicate stratospheric injections not far from these lats.

There is no significant difference between artificial $\mathrm{C}^{14}$ values for Terre Adélie and Kerguelen, these curves are very similar to those obtained, e.g., at Makara, New Zealand (41 ${ }^{\circ} 18^{\prime} \mathrm{S}$ Lat, $74^{\circ} 14^{\prime} \mathrm{E}$ Long) (Rafter and O'Brien, 1970). Values in 1967 and 1968 are higher in Terre Adélie than in France. Coincidence of Antarctica values with those in $\mathbf{N}$ hemisphere appears approximately at end of 1967. Hence it may be estimated that entire troposphere reached fairly uniform $\mathrm{C}^{14}$ concentration ca. $5 \mathrm{yr}$ after cessation of main ( $\mathrm{N}$ hemisphere) nuclear atmospheric tests. 


\section{Spitsbergen series}

Atmospheric $\mathrm{CO}_{2}$ samples obtained by G. Lambert, Centre des Faibles Radioactivités, Gif-sur-Yvette, who participated in C.N.R.S. expedition in 1966 at $\mathrm{Ny}$-Alesund, in Spitsbergen $\left(78^{\circ} 55^{\prime} \mathrm{N}\right.$ Lat, $12^{\circ} 00^{\prime}$ E Long).

\begin{tabular}{lccccccc}
\hline Date no. & Sample no. & Month Day & Year & $\delta \mathrm{C}^{14 \%} \%$ & $\delta \mathrm{C}^{13 \%} \%$ & $\Delta \%$ \\
\hline Gif-2082 & $\mathrm{SP}_{1}$ & July & $7-8$ & 1966 & 871 & $(-11)^{*}$ & $819 \pm 14$ \\
Gif-2083 & $\mathrm{SP}_{2}$ & July $28-29$ & 1966 & 832 & $(-11)$ & $781 \pm 14$ \\
Gif-2084 & $\mathrm{SP}_{3}$ & Aug. & $4-5$ & 1966 & 846 & $(-11)$ & $795 \pm 14$ \\
Gif-2085 & $\mathrm{SP}_{4}$ & Aug. 17-18 & 1966 & 826 & $(-11)$ & $775 \pm 14$ \\
Gif-2086 & $\mathrm{SP}_{5}$ & Aug. 26-27 & 1966 & 878 & $(-11)$ & $824 \pm 14$ \\
\hline
\end{tabular}

$* \delta \mathrm{C}^{13}$ assumed

Comment: these Spitsbergen values are ca. $10 \%$ higher than those of I. Olsson (R., 1970, v. 12, p. 283) during same period. Discrepancy has not yet been explained.

\section{REFERENCES}

Bigarella, J. J., 1965, Subsidios para estuda dos variaçoes de nivel Oceanico no Quaternario Brasileiro: Anais da Academia Brasileira de Siencias, v. 37, p. 263-277.

Bellair, N. and Delibrias, G., 1967, Variations climatiques durant le dernier millénaire aux îles Kerguelen: Acad. sci. [Paris] Comptes rendus, t. 264, p. 2085-2088.

Briard, J., 1968. Un tumulus du Bronze Ancien à Lescongar en Plouhinec: GalliaPréhistoire, v. 11, p. 247-259.

1970, Un tumulus du Bronze Ancien: Kernonen en Plouvorn (Finistère): L'Anthropologie, t. 74, p. 5-55.

Calderon, V., 1964, O sambaqui da Pedra Oca, officinas da imprensa baiana de economia: Fac. Ciencas Economicas Univ. de Bahia, Salvador, Bahia, Brazil.

Coursaget, J. and Le Run, J., 1966, Gif-sur-Yvette natural radiocarbon measurements I: Radiocarbon, v. 8 , p. $128-141$.

Courtin, J., 1963, Cahiers ligures de Préhistoire et d'Archéologie: v. 12, p. 214-215.

De Beaulieu, J. L., 1969, Analyses polliniques dans les Monts de l'Espinouse (Hérault): Pollen et spores, v. 11, no. 1, p. 83-96.

De Lanfranchi, F., 1967, La grotte sépulcrale de Curacchiaghiu (Lévie, Corse): Soc. Préhist. Fr. Bull., t. LXIV, p. 587-612

Delibrias, G. and Guillier, M. T., The sea level on the Atlantic coast and the Channel for the last 10,000 years by the $\mathrm{C}^{14}$ method: Quaternaria, in press.

Delibrias, G., Elhai, H., and Larsonneur, C., 1969, Le Flandrien à l'Est d'Arromanches (Calvados): Acad. Sci. [Paris] Comptes rendus, t. 268, p. 247-250.

Delibrias, G., Guillier, M. T., and Labeyrie, J., 1964, Saclay natural radiocarbon measurements I: Radiocarbon, v. 6, p. 233-250. 236-244. 1965 , Saclay natural radiocarbon measurements II: Radiocarbon, v. 7, p.

74-95. 1966, Gif natural radiocarbon measurements II: Radiocarbon, v. 8, p. 421-443.

Dupont, B. and Delibrias, G., 1970, Note à propos de la datation par le carbone 14 d'un niveau sédimentare de l'archipel du Lac Tchad: Cahiers O.R.S.T.O.M., v. 2 , no. 1 , p. 49-60.

Emphoux, J. P., 1970, La grotte de Bitorri au Congo-Brazzaville: Cahiers O.R.S.T.O.M., v. 7 , no. 1 , p. $1-20$. 
Engel, F., 1964, El preceramico sin algodon en la costa del Perú: Actas y Memorias, v. 3, 35th Cong. Internatl. de Americanistas, Mexico, 1962, p. 141-152.

Gaussen, J. and Gaussen, M., 1960, Les pointes de la basse vallée du Tilemsi: Soc. African Jour., v. 30, p. 123-143.

Giot, P. R., 1965, Le briquetage de Kerlavos: Annales Bretagne, v. 72, p. 87-94. 1968, Chronique des datations radiocarbone armoricaines: Annales Bretagne, v. 75 , p. $153-164$.

- 1969, Chronique des datations radiocarbone armoricaines: Annales Bretagne, v. 76, p. 153-162.

— 1970, Chronique des datations radiocarbone armoricaines: Annales Bretagne, v. 77, p. 155-160.

Giot, P. R. and Briard, J., 1969, Les retranchements du Cap d'Erquy: Annales Bretagne, v. 76, p. 21-36.

Giot, P. R. and Doucouret, J. P., 1968, Le souterrain de l'âge de Fer de Kervéo en Plomelin (Finistère): Annales Bretagne, v. 75, p. 101-116.

Glemarec, M., 1969, La "Grande Vasière", aperçu bionomique: Acad. Sci. [Paris] Comptes rendus, t. 268, p. 155-157.

Gouletquer, P. L., 1967, Le briquetage de Mesperleuch en Plouhinec (Finistère): Annales Bretagne, v. 74 , p. 107-119.

1970, Les briquetages armoricains: Doc. Sci. thesis, Fac. Sci., Rennes, 190 p.

Gouletquer, P. L., Lejards, J., and Tessier, M., 1968, Les sites à augets de la côte S. de la Bretagne: Annales Bretagne, v. 75, p. 117-148.

Guilaine, J. and Abelanet, J., 1965, La céramique poladienne du Roussillon et du Bassin de l'Aude: Symposium Prehist. Peninsular Proc., Pamplona.

Guyader, Y., 1969, Fouille d'un souterrain de l'âge du Fer à Grohan en Quessoy, (Côtes du Nord): Annales Bretagne, v. 76, p. 61-84.

Joussaume, R., 1968, Tumulus campaniforme à Jard (Vendée): L'Anthropologie, v. 72 , p. $545-551$.

Labeyrie, J., Delibrias, G., and Guillier, M. T., 1968, Vitesse moyene de sédimentation depuis la fin du Würm dans la plaine abyssale de la Méditerranée Occidentale: Acad. Sci. [Paris] Comptes rendus, t. 264, p. 1370-1372.

Léger, M., 1965, Les terrasses du Danuble de Regensburg à Pleinting: Assoc. Fr. Etude du Quaternaire Bull., v. 2, p. 153-164.

Le Provost, F. M. and Giot, P. R., 1966, La céramique d'un site de surface au Miniou en Bonen (Côtes du Nord): Annales Bretagne, v. 73, p. 43-49.

Le Roux, C. T., 1966, Le tumulus de l'âge du Bronze du Hellen en Cleder (Finistère): Annales Bretagne, v. 73, p. 32-37.

Le Roux, C. T. et l'Helgouach, J., 1967, Le Cairn mégalithique avec sépultures à chambres compartimentées de Kerleven (Finistère): Annales Bretagne, v. 74, p. 7-52.

l'Helgouach, J., 1966, Fouilles de l'allée ouverte de Prajou-Menhir en Trebeurden (Côtes du Nord): Soc. Préhist. Fr. Bull., v. 63, p. $311-342$.

1967, La sépulture mégalithique à entrée latérale de Crec'h-Quillé en Saint-Quay-Perros, (Côtes du Nord): Soc. Préhist. Fr. Bull., v. 65, p. 659-698.

Masset, C., 1968, Les incinérations du Néolithique ancien de Neuvy-en-Dunois: Gallia, t. 11, fasc. 1, p. 205-232.

Mauny, R., 1955, Les gisements néolithiques de Karkarichinkat (Tilemsi, Soudan Français): C. E. II, Panafricain Préhist. Cong. Alger, p. 616-626.

Mauny, R., Gaussen, J., and Gaussen, M., 1968, Commentaires sur la datation au carbone 14 de deux villages néolithiques du Sahara malien I.F.A.N. Bull., v. 30 , ser. B, no. 4, p. 1317-1321.

Michel, J. P., 1968, Etude sédimentologique des forages dans l'estuaire de la Seine (Port du Havre): Soc. Géol. de Normandie, Bull., v. 58, p. 9-16.

Morzadec-Kerfourn, M. T., 1969, Variations de la ligne de rivage au cours du postglaciaire le long de la côte nord du Finistère: Assoc. Fr. Etude Quaternaire Bull., v. 6, p. $285-318$

Olsson, I. U. and Klasson, M., 1970, Uppsala radiocarbon measurements X: Radiocarbon, v. 12 , p. $281-284$

Ottman, F. and Urien, M., 1966, Sur quelques problèmes sédimentologiques dans le Rio de Plata: Rev. Géog. Phys. et Géol. Dyn., v. 3, fasc. 3, p. 209-224.

Paccard, M., 1966, Nouvelles découvertes à Gramari (Méthamis, Vaucluse): Soc. Préhist. Fr. Bull., v. 62 , p. 150-151.

Pautot, G., 1967, Structure sous-marine du haunt-fond du Mćjean, Acad. Sci. [Paris] Comptes rendus, t. 265, p. 1028-1030. 
Rafter, T. A. and O'Brien, B. J., 1970, Exchange rates between the atmosphere and the ocean as shown by recent $\mathrm{C}^{14}$ measurements in the South Pacific: Nobel symposium 12 on radiocarbon variations and absolute chronology Proc., Uppsala, p. 355-377.

Servant, M., Servant, S., and Delibrias, G., 1969, Chronologie du Quaternaire récent des basses régions du Tchad: Acad. Sci. [Paris] Comptes rendus, t. 269, p. 1603-1606.

Thatcher, L., Rubin, M., and Brown, G. S., 1961, Dating desert ground waters: Science, v. 134, p. 105-106.

Thurber, D. L., Broecker, W. S., Blanchard, R. L., and Potratz, H. A., 1965, Uranium series age of Pacific atoll coral: Science, v. 149, p. 55-58.

Van Andel, T. H. and Laborel, J., 1964, Recent high relative sea-level stand near Recife, Brazil: Science, v. 145, p. 580-581.

Van Campo, M. and Jalut, C., 1969, Analyse pollinique de sédiments des Pyrénées orientales: Lac de Balcère (1764 m): Pollen et Spores, v. 11, no. 1, p. 117-126. 